\title{
Co-Creation in Practice II: Co-creating a Digital Walking Guide (Bremen Hemelingen)
}

\section{Summary of Co-creation Project ${ }^{1}$}

\section{Problem Focus}

One dimension of the World Health Organization's age-friendly cities and communities guidelines is the provision of age-friendly outdoor spaces to allow older adults spending more time outdoors. From a public health perspective this is particularly relevant, as spending more time outdoors improves people's functional health and ensures Vitamine D take-up. Hence, one of the tasks of social care service providers is to organise joint outdoor activities in order to activate older adults to exercise and to meet other people.

\section{Value Proposition}

A digital information service around local walking tours allows, compared to printed guides, for more detailed and up-to-date information as well as greater information richness. Walks and related locations can be presented by adding video clips of people conducting those walks and voice recordings of recommendations by members of the target audience, which gives the information a lively and personal touch. We developed a digital service that provides relevant and appealing information to older adults which activates and motivates joint walks in the different parts of the district and supports service providers in organising and announcing these kinds of walks by exploiting the potential of multimedia technologies.

\footnotetext{
${ }^{1}$ This introduction is derived from the case study of our interactive co-creation guide: https://cocreation.mobile-age.eu/guidebook/case-studies/bremen.

This chapter is based on the Mobile Age project deliverable D3.2 Senior Citizen Engagement Report Bremen: https://mobile-age.eu/images/pdf/deliverables/WP3/D3.2.pdf.
} 


\section{Limitations of Existing Services}

Existing services (such as a printed pocket guide, a district website, flyers and posters in meeting places) are not comprehensive, and limited in their appeal to motivate outdoor and social activities of older adults. An existing printed pocket guide for the district informs about nice places and walks but it lacks appealing information that has the potential to attract people to visit places they did not know before. Furthermore, certain features important for older adults such as up-to-date information on benches and toilets are missing.

\section{Field Site}

This co-creation project was conducted in the district of Hemelingen in Bremen, Germany. Hemelingen is located in the east of Bremen, connected directly with the inner-city district in its Western part. Hemelingen is the second largest city district in Bremen. It is divided into five neighbourhoods each of which is an important point of identification and reference for its residents. Some of the neighbourhoods have a rural character as they are situated on the outskirts of Bremen, whereas others go seamlessly into one of the most popular city districts and have an urban flair. The share of each of the neighbourhood's foreign population differs between $6.3 \%$ and $23.6 \%$. This segregation manifests in people's attitudes towards each other and "their" neighbourhoods. One important aim of urban development processes in this district is therefore to overcome such divides and establish of a sense of shared identity.

\section{Co-created Service}

The result of this co-creation project was a digital walking guide for older adults that provides appealing multi-media information on several walks in the different parts of the district. It is integrated in the official online portal of the city of Bremen ${ }^{2}$ and is maintained there since our project finished. On top of the information about walks, the guide provides also general information about the district (e.g. meeting places, consulting). The content of the digital district guide, has also been printed in a booklet featuring six walks. This was co-financed by the Mobile Age project and the district council. The booklet is distributed via local social care service providers and reaches out to older adults who do not use digital devices. In addition, two of the senior citizen meeting places instigated tablet groups for older adults after the project finished. Part of the reason was that a demand for such a service became apparent through our project.

\section{Rationale for Selection of Field Site}

There are a number of reasons for why we selected Bremen Hemelingen, most of them derived from our lessons learned in Bremen Osterholz. Table 1 provides an overview on the lessons learned from Bremen Osterholz and the actions that were to be implemented in the next co-creation phase. It further explains why Bremen Hemelingen was chosen for the second co-creation project.

\footnotetext{
${ }^{2}$ www.bremen.de/hemelingen/senioren.
} 
Table 1 Rationale for selection of district based on lessons learned from first co-creation process

\begin{tabular}{|c|c|c|c|}
\hline & $\begin{array}{l}\text { Lessons learned } \\
\text { derived from } \\
\text { Osterholz }\end{array}$ & $\begin{array}{l}\text { Actions to be implemented in } \\
\text { second co-creation process }\end{array}$ & Hemelingen \\
\hline \multirow[t]{2}{*}{ Planning } & $\begin{array}{l}\text { O-1.1: Start with an } \\
\text { existing group of } \\
\text { relevant data } \\
\text { providers }\end{array}$ & $\begin{array}{l}\text { Identify a district in which a } \\
\text { printed neighbourhood guide } \\
\text { already exists as a basis for } \\
\text { data and identify the group of } \\
\text { people that produced it }\end{array}$ & $\begin{array}{l}\text { In Hemelingen there is an } \\
\text { existing network of local } \\
\text { service and care } \\
\text { providers ("Alte } \\
\text { Vielfalt") }\end{array}$ \\
\hline & $\begin{array}{l}\text { O-1.2: Establish } \\
\text { project group of local } \\
\text { stakeholders }\end{array}$ & $\begin{array}{l}\text { Identify a district in which a } \\
\text { network of service providers } \\
\text { already collaborates and } \\
\text { which may be interested in } \\
\text { extending their collaboration } \\
\text { to the development of a } \\
\text { digital district guide }\end{array}$ & \multirow[t]{2}{*}{$\begin{array}{l}\text { Six members of the } \\
\text { network "Alte Vielfalt" } \\
\text { signaled interest in } \\
\text { joining the project group } \\
\text { and supporting our } \\
\text { co-creation activities }\end{array}$} \\
\hline $\begin{array}{l}\text { Engaging } \\
\text { stakeholders }\end{array}$ & $\begin{array}{l}\text { O-2.3: Engage } \\
\text { intermediaries to } \\
\text { support recruitment }\end{array}$ & $\begin{array}{l}\text { Identify a network/group of } \\
\text { service and care providers, } \\
\text { which facilitate recruitment } \\
\text { within the context of their } \\
\text { work }\end{array}$ & \\
\hline $\begin{array}{l}\text { Co-creating a } \\
\text { service } \\
\text { concept }\end{array}$ & $\begin{array}{l}\text { O-3.2: Consider } \\
\text { intermediaries as } \\
\text { main users of a } \\
\text { service }\end{array}$ & $\begin{array}{l}\text { Identify intermediaries, such } \\
\text { as service and care providers } \\
\text { and investigate how a digital } \\
\text { service could support their } \\
\text { work }\end{array}$ & $\begin{array}{l}\text { Through the network } \\
\text { "Alte Vielfalt" we had } \\
\text { access to a variety of } \\
\text { service providers to } \\
\text { explore how the service } \\
\text { could support their work }\end{array}$ \\
\hline $\begin{array}{l}\text { Co-creating } \\
\text { (open) data }\end{array}$ & $\begin{array}{l}\text { O-4.1: Take into } \\
\text { account that } \\
\text { information } \\
\text { identified as relevant } \\
\text { may not be available } \\
\text { as open data }\end{array}$ & $\begin{array}{l}\text { Plan ahead to collaborate } \\
\text { with various data owners (e.g. } \\
\text { service providers) and allow } \\
\text { sufficient time for data } \\
\text { creation during the } \\
\text { co-creation process. } \\
\text { Offer a user-friendly backend } \\
\text { for inputting data to } \\
\text { participants }\end{array}$ & $\begin{array}{l}\text { In Hemelingen a printed } \\
\text { neighbourhood guide } \\
\text { which provides basic data } \\
\text { about the district already } \\
\text { exists }\end{array}$ \\
\hline Exploiting & $\begin{array}{l}\text { O-6.1: Sustainability } \\
\text { remains a big } \\
\text { challenge }\end{array}$ & $\begin{array}{l}\text { Identify local stakeholders } \\
\text { that can sustain the } \\
\text { maintenance of the service } \\
\text { early in the process (e.g. } \\
\text { identify ways in which the } \\
\text { service serves their interests/ } \\
\text { supports their work) }\end{array}$ & $\begin{array}{l}\text { With a stable and active } \\
\text { network of local service } \\
\text { providers, the likelihood } \\
\text { of identifying actors } \\
\text { willing to sustain the } \\
\text { service increases }\end{array}$ \\
\hline
\end{tabular}

\section{Introduction to Field Site}

As field site for the second co-creation project, we chose the city district Hemelingen. Hemelingen has in total 42,415 inhabitants of which 19,8\% $(8,394)$ were 65 years or older in 2015, which is similar compared to overall Bremen with 21, 2\%. By 
2020 , the number of retired adults is expected to increase to 8.683 .

Hemelingen is located in in the east of Bremen, connected directly with the inner-urban area in its western part. Hemelingen is the second largest city district in Bremen. It is divided into five neighbourhoods (Hemelingen, Sebaldsbrück, Hastedt, Arbergen and Mahndorf) of which each is an important point of identification and reference for the residents (Table 2).

The orientation towards the neighbourhoods is partly due to the relatively late incorporation of former autonomous villages into the city structure and to the different socio-demographics. It is facilitated by "natural barriers" like big roads that divide the neighbourhoods and hinder physical crossing. The size and diversity of the district foster the division further. For instance, the neighbourhoods of Arbergen and Mahndorf on the outskirts of Bremen have a rural character, whereas Hastedt in the east goes seamlessly into one of the most popular city districts and like Hemelingen and Sebaldsbrück has a more urban flair. Arbergen also has the lowest share of foreign population with 7, 4\% compared to Hemelingen with the highest share of 23,6\%. The unemployment rate is highest in Hemelingen $(16,3 \%)$ and lowest in Arbergen (6, 3\%). Arbergen has with $25 \%$ of people above 65 years the largest share of older adults (compared to the average of 19,8\% for the whole district of Hemelingen). This segregation manifests in people's attitudes towards each other. One important aim of urban development processes therefore is the overcoming of these divides and the establishment of a sense of shared identity (Fig. 1).

Figure 2 shows how big the district is in comparison to Osterholz. It also visualises how the different neighbourhoods are divided by major roads and railways.

\section{Co-creation Process}

\section{Governing and Managing Co-creation}

In our first co-creation project in Bremen Osterholz, we collected a number of lessons learned for each of the streams of activity. These lessons learned informed the planning of our second co-creation project in Bremen Hemelingen (Table 3).

Table 2 Overview Bremen Hemelingen

\begin{tabular}{l|l|l|l}
\hline The neighbourhoods & Size & Number of inhabitants & Of which aged 65 and above \\
\hline Sebaldsbrück & 509 ha & 10,010 & 2,144 \\
\hline Hastedt & 286 ha & 10,674 & 1,813 \\
\hline Hemelingen & 934 ha & 10,649 & 1,786 \\
\hline Arbergen & 602 ha & 5,950 & 1,504 \\
\hline Mahndorf & 644 ha & 5,627 & 1,244 \\
\cline { 3 - 4 } Total district & & 42,910 & 8,491 \\
\hline
\end{tabular}



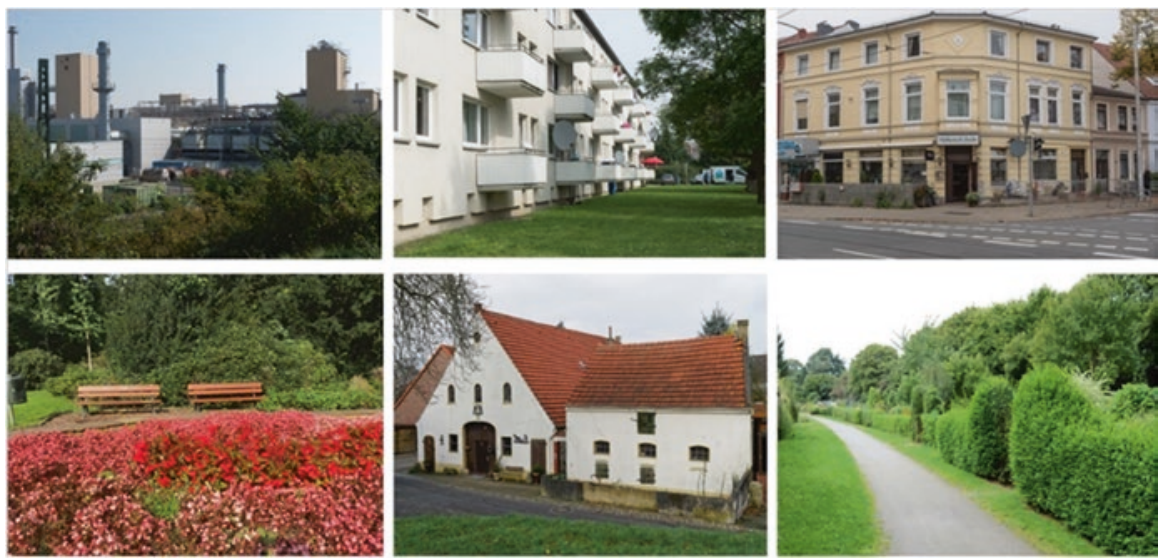

Fig. 1 Impressions from the different neighbourhoods in Bremen Hemelingen

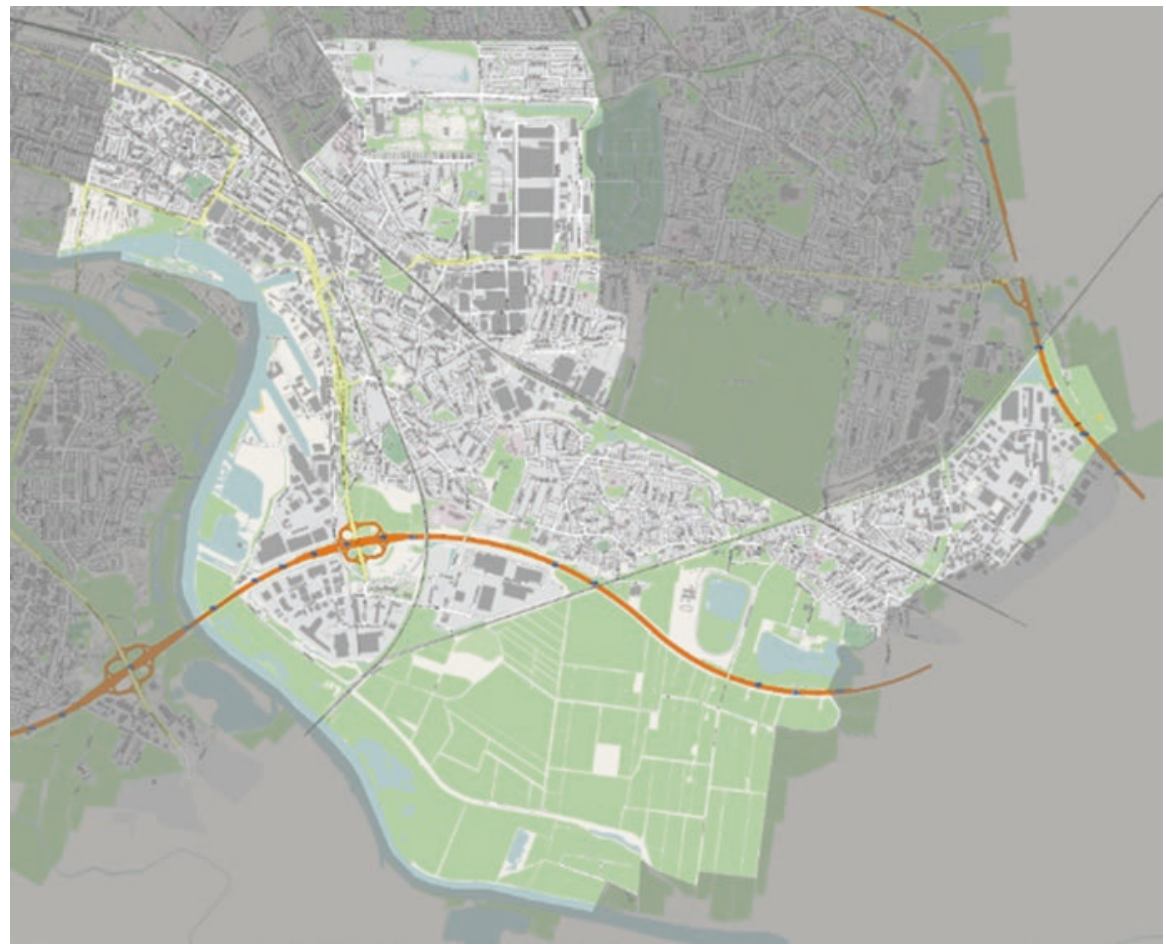

Fig. 2 Map Bremen Hemelingen (neighbouring to Osterholz to its North) 
Table 3 Lessons learned for planning the second co-creation project

\begin{tabular}{l|l|l}
\hline & $\begin{array}{l}\text { Lessons learned derived } \\
\text { from Osterholz }\end{array}$ & Actions to be implemented in second co-creation project \\
\hline Planning & $\begin{array}{l}\text { O-1.1: Start with an } \\
\text { existing group of } \\
\text { relevant data providers }\end{array}$ & $\begin{array}{l}\text { Identify a district in which a printed neighbourhood guide } \\
\text { already exists as a basis for data and identify the group of } \\
\text { people that produced it }\end{array}$ \\
\hline $\begin{array}{l}\text { O-1.2: Establish project } \\
\text { group of local } \\
\text { stakeholders }\end{array}$ & $\begin{array}{l}\text { Identify a district in which a network of service providers } \\
\text { already collaborates and which may be interested in } \\
\text { extending their collaboration to the development of a } \\
\text { digital district guide }\end{array}$ \\
\hline $\begin{array}{l}\text { O-1.3.: Consider } \\
\text { activities that are } \\
\text { feasible }\end{array}$ & $\begin{array}{l}\text { Cut down on the cultural probes pack, to make it less time } \\
\text { consuming for participants and facilitators }\end{array}$ \\
\hline $\begin{array}{l}\text { O-1.4.: Consider } \\
\text { activities that support } \\
\text { use of technology }\end{array}$ & $\begin{array}{l}\text { Allow more time in the co-creation process for participants } \\
\text { to get acquainted with technology. } \\
\text { Offer tablet support groups outside of the core co-creation } \\
\text { activities }\end{array}$ \\
\hline $\begin{array}{l}\text { O-1.5: Establish } \\
\text { transparent decision- } \\
\text { making procedures }\end{array}$ & $\begin{array}{l}\text { Establish a procedure to document the process and } \\
\text { decision-making to all participating stakeholders }\end{array}$ \\
\hline $\begin{array}{l}\text { O-3.2: Consider } \\
\text { intermediaries as main } \\
\text { users of a service }\end{array}$ & $\begin{array}{l}\text { Identify intermediaries, such as service and care providers } \\
\text { and investigate how a digital service could support their } \\
\text { work }\end{array}$ \\
\hline
\end{tabular}

\section{Target Audience}

Based on our learnings from Osterholz, we wanted to target two different stakeholder groups in this project (O-3.2): Older adults in their Third Age and service providers, i.e. intermediaries that provide services for older adults in the district. The rationale for targeting not only older adults but also service providers was twofold: firstly, we wanted to foster existing support structures in accordance with our aim to embed the co-created service in already existing service structures. Secondly, regarding the persistent exclusion of a large part of older adults from the use of the internet and related devices and programmes, we aimed to expand the impact of the co-created service to a broader audience by targeting service providers.

\section{Problem Focus}

The problem focus in the second co-creation project was again on social inclusion. In the first project (Osterholz), we aimed to develop a comprehensive information service. The following two recommendations were important for the refinement of the problem focus in Hemelingen (Table 4).

In our initial meeting with the network of service providers in the district called "Alte Vielfalt" (Old Variety) care takers affirmed that nice places and walks, as included in the Osterholz app were of great interest, but the description of these places alone was not activating (older adults to actually go there). One main task of their work with older adults is the organisation of joint outdoor activities in order to activate older adults to exercise and to meet other people. Furthermore, like in 
Table 4 Lessons learned for problem focus in second co-creation process

\begin{tabular}{l|l}
\hline $\begin{array}{l}\text { Recommendations derived from } \\
\text { Osterholz }\end{array}$ & $\begin{array}{l}\text { Actions to be implemented in second co-creation } \\
\text { process }\end{array}$ \\
\hline $\begin{array}{l}\text { O-3.3: Consider a service that is more } \\
\text { activating/beyond information } \\
\text { provision }\end{array}$ & $\begin{array}{l}\text { Identify and implement potential services that could } \\
\text { complement the information provided in a digital } \\
\text { district guide }\end{array}$ \\
\hline $\begin{array}{l}\text { O-4.2: Less is more. Concentrate on a } \\
\text { few categories of objects }\end{array}$ & $\begin{array}{l}\text { Identify and concentrate on a manageable number of } \\
\text { categories of objects (in line with the human resources } \\
\text { available and involved in the co-creation process) }\end{array}$ \\
\hline
\end{tabular}

Osterholz, in Hemelingen the issue of segregation in the district, a lack of shared identity and mutual prejudices particularly amongst older residents was considered a problem. We learned that the limitation of the mobility patterns and interests of the majority of (older) people in the district is also a social issue: socially disadvantaged people are more likely to have a narrower radius. Therefore the service providers (and later on also the participating older adults) considered it important to provide information on the district as a whole and not separate neighbourhoods.

\section{Limitations of Existing Information Services}

In addition to the limitations of existing information services for Bremen overall, that were detected in our first co-creation project, we identified the following existing information services for Hemelingen:

- a printed neighbourhood pocket guide had been put together by local stakeholders in 2016. The guide contains information on recreational spaces, meeting places, creative and cultural offers, events, institutions and facilities, possibilities for lunch, sport, infrastructure, living and consulting as well as nice routes for walking. The data in the Mobile Age app are based on this printed guide.

- The district marketing conducted a survey about places to meet and eat which were published on the districts' Website.

- The network "Alte Vielfalt" publishes guides for older adults in Hemelingen (biannually) that contain comprehensive information on services and facilities for older adults in the district

- The district marketing runs a website where anyone who organises events or activities can announce these.

- A great variety of flyers announcing events and activities.

Only the pocket guide designed for and with older adults includes a few walks in different neighbourhoods of the district (Fig. 3). However, information provided is minimal. Besides the highlighted way on a small map the description on the left hand side only mentions the starting point and the lengths of the walk as well as references to two points of interest. For example benches and toilets, deemed relevant by the co-creators in Osterholz, are not featured nor are most of the attributes that were defined as important and relevant during our first co-creation project. 
With regard to the problem focus, the limitation of these services is that they do not inform about activities and/or events for older adults in an activating way, which means in a way that motivates older adults who are not already active anyway.

\section{Value Proposition and Expected Impact}

A digital service not only allows for more space and richer information as already demonstrated with the Osterholz service. In addition, walks can be presented with even greater information richness by adding video clips of people moving and voice recordings of recommendations by participant. Our value proposition for the second co-creation process was therefore:

Provide relevant and appealing information to older adults which activates and motivates joint walks in the district and supports service providers in organising and announcing these kinds of walks by exploiting the full potential of multimedia technologies.

kurze Spazierrunden

28 A in Hemelingen

ab Haltestelle Glockenstraße oder Hemelinger Bahnhofstraße

ca $1,8 \mathrm{~km} \mid \mathrm{s}$. rechts

$35 \quad 36 \quad$ B beim Schlengpark

ab Haltestelle Schlengstraße

ca $2 \mathrm{~km}$ | s. Karte vorn

697377 C in Arbergen

ab Haltestelle Nauheimer Straße

ca. $2 \mathrm{~km}$ | s. Karte hinten

Ausflüge

32 NABU

Tages-, Wochenend- und

50plus-Touren ins Grüne

Vahrer Feldweg 185

Radtouren mit dem ADFC

z.B. Hastedter Montagstour,

www.adfc-bremen.de

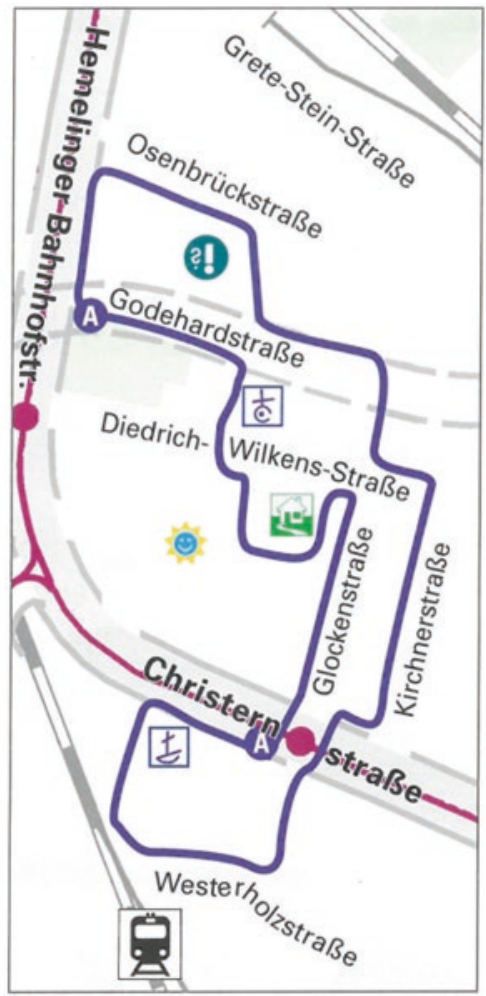

Fig. 3 Example of walk in printed neighbourhood guide 
The expected impact was that due to the more activating way of presenting walks more older adults in the district would participate in walking tours. This would encourage walks not only in their own neighbourhood but also in others. In addition, we expected that the information provided also improves the advertisement of walking tours by the service providers and intermediaries.

\section{Engaging Stakeholders}

Before describing our engagement activities in more detail, the following table provides an overview about the key lessons learned for these activities and how we planned to implement them in the second co-creation project (Table 5).

\section{Engaged Co-creators}

Our learning from the first phase had shown that we had focussed too much on the engagement of older adults. Therefore, in Hemelingen we aimed to engage different groups of people to support the co-creation projects in different ways from the beginning (O-2.1). In order to build the service on existing data, we therefore initially identified the group of people that had produced the printed district guide (O-1.1). This was a network of elderly care service providers called "Alte Vielfalt". Another main insight from Bremen Osterholz was that the recruitment of older adults is most successful when processed through local intermediaries (O-2.3). The network "Alte Vielfalt" turned out to be the appropriate stakeholder group also in this regard. Another advantage of including this group was that they could host the co-creation meetings, that they had an interest as target group (and potential users) in supporting the co-creation process and that they could potentially maintain the co-created service (O-3.2). We attended one of the regular meetings of this group and presented the project and our request. The response was predominantly positive- the members of the network expressed their appreciation for our commitment to the district and their willingness to engage in the project. From the whole network 7 members committed themselves to be part of a "project board" that would recruit different groups of older adults for the co-creation process and that would accompany and support the whole process (O-1.2).

As result from our experiences from the first co-creation project, we decided not to engage with individual older adults in the form of one core project group and additional co-creators, but to involve different existing groups in different phases of the process (O-2.5). Through this approach, we wanted to make sure that people from different neighbourhoods and with different skills and knowledge get involved. By using certain resources for specific purposes in the different phases we wanted to lower the barriers for participation, firstly because it becomes possible to participate selectively in certain tasks and secondly because it is not required to commit to the whole process of 6 months. The members of our project board "Alte Vielfalt" recruited three existing groups in three different neighbourhoods for initial focus groups: 
Table 5 Lessons learned for engaging stakeholders in the second co-creation project

\begin{tabular}{|c|c|c|}
\hline & $\begin{array}{l}\text { Lessons learned derived } \\
\text { from Osterholz }\end{array}$ & $\begin{array}{l}\text { Actions to be implemented in second co-creation } \\
\text { project }\end{array}$ \\
\hline \multirow[t]{3}{*}{ Planning } & $\begin{array}{l}\text { O-1.1: Start with an } \\
\text { existing group of relevant } \\
\text { data providers }\end{array}$ & $\begin{array}{l}\text { Identify a district in which a printed } \\
\text { neighbourhood guide already exists as a basis for } \\
\text { data and identify the group of people that } \\
\text { produced it }\end{array}$ \\
\hline & $\begin{array}{l}\text { O-1.2: Establish project } \\
\text { group of local } \\
\text { stakeholders }\end{array}$ & $\begin{array}{l}\text { Identify a district in which a network of service } \\
\text { providers already collaborates and which may be } \\
\text { interested in extending their collaboration to the } \\
\text { development of a digital district guide }\end{array}$ \\
\hline & $\begin{array}{l}\text { O-1.5: Establish } \\
\text { transparent decision- } \\
\text { making procedures }\end{array}$ & $\begin{array}{l}\text { Establish a procedure to document the process } \\
\text { and decision-making to all participating } \\
\text { stakeholders }\end{array}$ \\
\hline \multirow[t]{5}{*}{$\begin{array}{l}\text { Engaging } \\
\text { stakeholders }\end{array}$} & $\begin{array}{l}\text { O-2.1: Identify the role } \\
\text { of intermediaries in } \\
\text { co-creation process }\end{array}$ & $\begin{array}{l}\text { Consider the different roles of intermediaries and } \\
\text { explain expectations well in advance (e.g. role of } \\
\text { local government, role of service providers in } \\
\text { process) }\end{array}$ \\
\hline & $\begin{array}{l}\text { O-2.2: Consider context } \\
\text { in which older adults are } \\
\text { invited to participate }\end{array}$ & $\begin{array}{l}\text { Identify a network/group of service and care } \\
\text { providers which can host the co-creation process } \\
\text { and facilitate recruitment within the context of } \\
\text { their work }\end{array}$ \\
\hline & $\begin{array}{l}\text { O-2.3: Engage } \\
\text { intermediaries to support } \\
\text { recruitment }\end{array}$ & $\begin{array}{l}\text { Identify a network/group of service and care } \\
\text { providers, which facilitate recruitment within the } \\
\text { context of their work }\end{array}$ \\
\hline & $\begin{array}{l}\text { O-2.4: Establish older } \\
\text { adults as experts }\end{array}$ & $\begin{array}{l}\text { If activities such as cultural probes are reduced } \\
\text { (O-1.1), find new ways of establishing older } \\
\text { adults' expertise early on in the process and allow } \\
\text { them to reflect on their practices for identifying } \\
\text { needs and resources }\end{array}$ \\
\hline & $\begin{array}{l}\text { O-2.5: Facilitate role } \\
\text { shift of older adults }\end{array}$ & $\begin{array}{l}\text { Define the co-creation process in a transparent } \\
\text { and clear way. Communicate tasks early on. } \\
\text { Identify interests and abilities of participating } \\
\text { older adults }\end{array}$ \\
\hline $\begin{array}{l}\text { Co-creating a } \\
\text { service concept }\end{array}$ & $\begin{array}{l}\text { O-3.2: Consider } \\
\text { intermediaries as main } \\
\text { users of a service }\end{array}$ & $\begin{array}{l}\text { Identify intermediaries, such as service and care } \\
\text { providers and investigate how a digital service } \\
\text { could support their work }\end{array}$ \\
\hline
\end{tabular}

- A tablet group in a senior residence home;

- A group of older adults that regularly participate in events and activities organised by the protestant church in the district;

- A group of people with mental health problems.

The engagement of the first and the third group was not successful. In the senior residence home, the older residents stated that there was no need for a district guide like we had planned to develop since the residents struggled with problems of physical as well as infrastructural mobility and hence did not see any relevance for a district guide that informs them about places they could not reach. 
The intermediary that had arranged the focus groups with people with mental health problems alerted us early on, that they would probably not be able to commit to a longer process. The idea with this focus group was to gain feedback on the Osterholz service and assess its relevance.

Later on different older adults from the different neighbourhoods were engaged in (parts of) the process. Most of them were recruited through the social activities manager of the protestant church in the neighbourhood Hemelingen and through the walking workshops that were announced as neighbourhood walks in different parts of the district. Some participants only showed up at a single intervention, others participated regularly. From the initial focus groups and the following activities, a group of 7 older adults formed that engaged in the data and design activities.

The local government was not involved as key partner. However, we presented the project to the local advisory council and kept a close communication with the head of the local district council.

Finally, FTB participated in the co-creation activities and implemented the app in continuous interaction and feedback loops.

Other organisations that were involved in specific parts of the project were

- ButenAktiv: a research team from the public health department of the University of Bremen that conducted a project on physical activities and ageing in the district. After an initial meeting, the collaboration was limited to the inclusion of one of their walks to our digital district guide.

- Accessible City Guide project: a bureau for urban planning that conducts a government-funded project on the accessibility of facilities and routes in the city and that collaborated with us on the measurement of barriers on walking routes.

Overall the following number of people per stakeholder group were involved (Table 6).

The co-creation streams in which they were engaged differed. For example, the biggest number of older adults was involved in the co-creation of the service concept (24) and the working with (open) data (36). Only few were involved in the cocreation of software (9) (Fig. 4).

Table 6 Number of people involved per stakeholder group

\begin{tabular}{l|l}
\hline Involved stakeholders & Number of people involved \\
\hline Older adults & 46 \\
\hline Local government & 5 \\
\hline Software developers & 2 \\
\hline Local service providers & 6 \\
\hline Co-creation facilitators & 5 \\
\hline Other organisations & 8 \\
\hline Intermediaries & 2
\end{tabular}




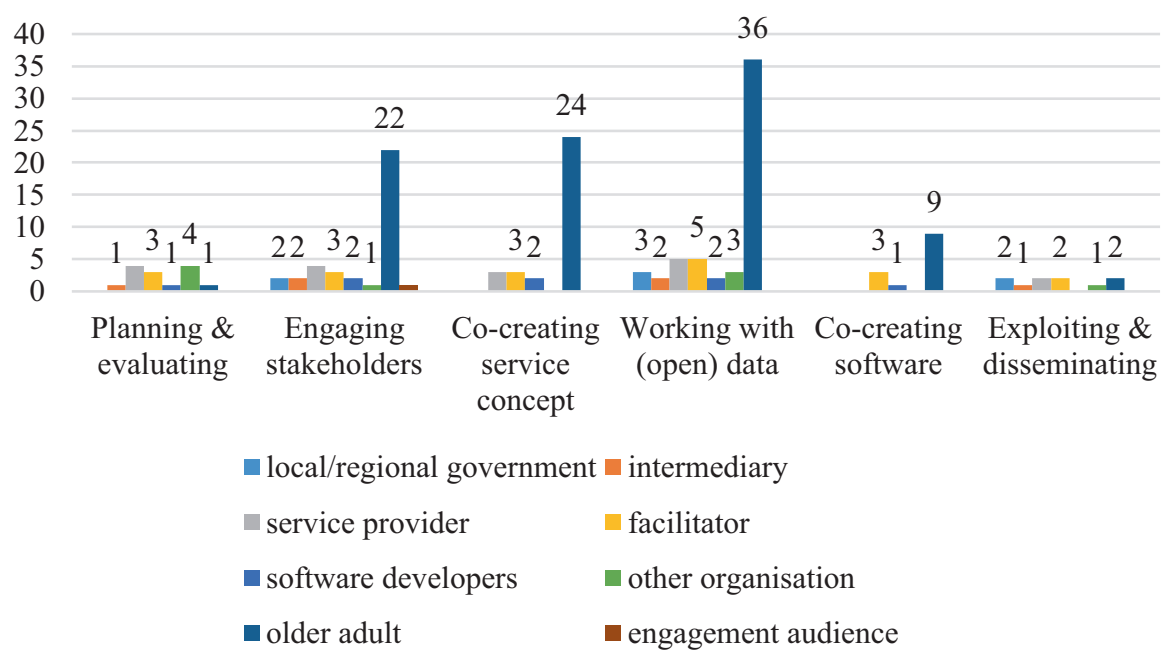

Fig. 4 Stakeholder engagement per co-creation stream

\section{Project Organisation/Governance}

In contrast to our project organisation in Bremen Osterholz where the core group was constituted by a group of older adults, in Bremen Hemelingen we followed a different governance structure by setting up a project board consisting of seven service providers, one older adult and three facilitators (researchers from ifib). In order to get a better understanding of the types of stakeholders involved, a brief overview is provided about the seven service providers in the following.

\section{Förderverein Familienzentrum MOBILE e.V.}

The Family Centre Mobile is a meeting place for all generations. It was planned with the participation of residents and experts from social institutions in the Hemelingen district and was built by the Bremen Society for Urban Renewal, Urban Development and Housing Construction. The planning and construction were funded by the European Union, the Federal Government, the City of Bremen as part of the "Living in Neighbourhoods" programme, the "Wohnliche Stadt" foundation in Bremen and the Hemelingen district advisory board. The association provides extensive groups and counselling for children, families and older adults. They also provide professional guidance on further assistance in family matters of any kind. The services for older adults comprise a senior citizens' café, a breakfast and lunch, special offers, trips for senior people and various small projects can also be taken up or supported in the family centre. After our project an IT-support group for older adults was planned, where older adults can learn about PC's, Smartphones, tablets and Internet applications.

\section{Aufsuchende Altenarbeit}

The project "Outreach Work with Older Adults" is a model project of the Bremen Senator for Social Affairs, Children, Youth and Women's Issues. It is now being carried out as a standard service of open care for the older people in four districts 
(amongst them Hemelingen). It helps and supports older adults who want to stay at home in their familiar surroundings as long as possible. Through visits and joint activities the aim is to counteract the threat of loneliness and thus noticeably improve the quality of life. Voluntary visitors regularly offer social activities and provide information on the district. Upon request, support is arranged or participation in events is organised.

\section{Bürgerhaus Hemelingen}

The community centres in Bremen are the cultural and social meeting points in the districts supported by the Bremen city administration. They are run by non-profit associations. They offer groups and courses for children, adolescents, adults, seniors, on a range of activities, covering hobbies, sports, health, entertainment, culture or languages. The community centres are run by full-time and volunteer staff. The community centre Hemelingen is the central cultural and social institution in the district. For seniors the community centre offers a yoga course for seniors $50+$, as well as a PC and Internet workshops and courses and painting courses. It houses a café, where people can meet even without consuming something.

\section{Begegnungszentrum der evangelischen Kirche Bremen Hemelingen}

The meeting centre is the community centre of the Protestant parish in the district. It is a meeting place for senior citizens' as well as children and includes a nursery. In addition to facilitating social encounters, it also organises concerts and festivities, counselling services and a broad range of activities for older adults.

\section{ASB}

The Arbeiter-Samariter-Bund Deutschland e. V. is a politically and religiously independent relief and welfare organisation. The section "mental health" is promoting mental health - through support for mentally ill people. The services are not specifically focussed on older adults. However, the representative from the organisation is actively involved in work with older adults in the district.

\section{Quartiersmanagement}

Due to special challenges in some parts of Bremen, various neighbourhood development programmes have been installed in the past, including Hemelingen. The neighbourhood management supports the implementation of ideas, the networking of actors and the application of additional funding. It coordinates the various activities, processes and funding programmes. Prerequisite for this is the cooperation in and initiation of networks as well as the support and activation of project sponsors and residents on site. The neighbourhood management is available to all actors and residents and operates both in the neighbourhood and in the political-administrative domain, in order to involve as many local actors as possible in the neighbourhood development and to act as an intermediary on different levels. The neighbourhood manager in Hemelingen targets isolation and segregation of disadvantaged people. She initiated projects to create opportunities for participation. With respect to older residents, she is involved in different projects in the district in cooperation with 
other organisations. She also offers consulting services for older people who suffer from poverty.

\section{Stadtteilmarketing}

The district marketing is an association that works as an interface between trade and commerce, business, administration, politics and citizens in Hemelingen. It plays an information and moderation role and mediates between voluntary and full-time organised claim and interest groups. Their aim is to promote Hemelingen as a "district worth living in". One main part of this task is to organise events and activities. Furthermore, the district marketing runs a website with comprehensive information on activities, events and services in the district. One focus is on older adults.

\section{Bremer Heimstiftung}

The Bremer Heimstiftung is a non-profit organisation offering residences to older citizens. The foundation is part of a civic network in Bremen. The organisation is represented in the network by the head of the residence "Arberger Mühle" in the neighbourhood Arbergen in Bremen Hemelingen.

The project board met regularly on a monthly basis. In total, there were six project board meetings (with an average of five members participating). Initially the main task of the project board was to explore issues that concerned older citizens and service providers in the district and to recruit groups of older adults for focus groups. The members of the project board also worked as important intermediaries for the involvement of further co-creators. During the process, we jointly reflected on the conducted activities and arranged the next steps. In the meetings, the facilitators presented the activities that had been conducted and got feedback from the group. Jointly we reflected on progress and problems that arose from the process. Additionally, the members of the project board were involved in the data creation and validation. One member of the project board, the social activities manager of the protestant community centre, took a special role in the process: She hosted all the project board meetings and most of the co-creation activities. She also organised and attended some of the co-creation activities.

In order to keep all involved stakeholders up-to-date with the process (O-1.5), we set up a blog with a project diary where we documented every single activity and its outcomes. In addition to a description of the project, the blog contained an entry for each activity as well as an announcement of the next activity (Fig. 5).

Each activity was described featuring

- the type of activity;

- its location, duration and date;

- a summary of the activities and outcomes (e.g. decisions),

- pictures

Below each entry, there is a comment box (Fig. 6). 


\section{MobilimAlter}

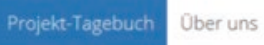

\section{Projekt-Tagebuch}

\section{Bildergalerie}

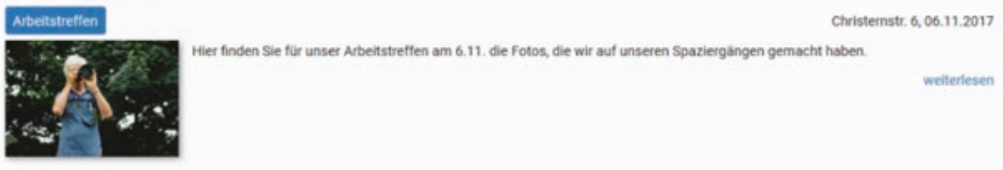

Dritte Tablet Werkstatt - Darstellung der Spaziergänge im digitalen Stadtteilführer

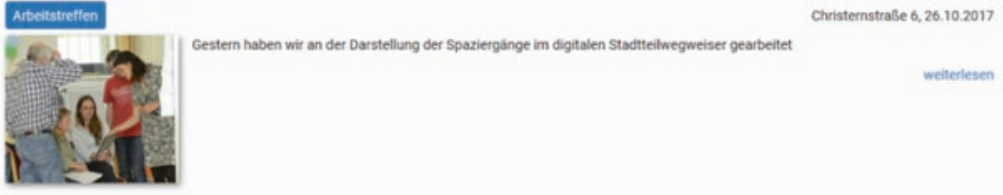

Datenerhebung zur Barrierefreiheit des Tamra-Park-Spaziergangs

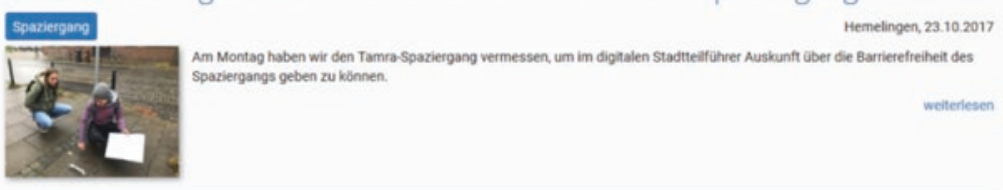

\section{Zweite Tablet-Werkstatt}

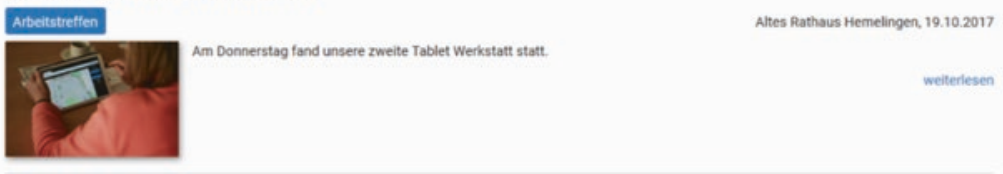

Fig. 5 The project blog

\section{Co-creating a Service Concept}

There were three key recommendations derived from our co-creation process in Osterholz that were relevant for the co-creation of a service concept. The table below outlines what actions we planned to implement in the second co-creation process (Table 7).

Initially, we conducted a preliminary survey and analysis of existing services. Subsequently, we ran two rounds of initial focus groups with three different groups of older adults in order to validate the service concept developed in Osterholz and receive some first ideas on a rough service concept. The three groups covered three 


\begin{tabular}{l|l}
\hline MobilimAlter $\quad$ Projekctagebuch Uber uns \\
\hline
\end{tabular}

\section{Test Spaziergang rund um das Bürgerhaus Hemelingen spaziegang \\ Ort der Veranstaltung \\ Christernstraße 6 \\ Dauer: \\ Datum:}

\section{Zusammenfassung des Treffens}

Am Donnerstag vergangener Woche haben wir erstmals mit unseren Teilnehmerinnen und Teilnehmern im Stadtteil Hernelingen die gemeinsam entwickelte Anwendung für Stadttell-Spaziergänge in Hemelingen getestet. Zusammen mit einer Gruppe von Hemelinger Seniorinnen und Senioren sowie Akteuren der Altenhilfe vor Ort haben wir dort seit letztem Sommer Stadttellspaziergänge gemacht und diese in einer Kartenanwendung dargestellt. Die Anwendung soll altere Menschen in den fünf Ortsteilen Hemelingens über schöne, interessante und gut begehbare Routen informieren und ithnen Lust machen ihren Stadtteil - auch Uber die Grenzen ihres jewelligen Ortsteils hinaus - zu erkunden. Neben geschichtlich interessanten Informationen findet man dort auch Angaben zur Erreichbarkeit, Barrierefreiheit, Sitzgelegenheiten, Tolletten und Einkehrmöglichkeiten. Zudern gibt es die Möglichkeit für lokale Anbieter von Veranstaltungen für altere Menschen, Stadtteilspaziergänge dort anzukundigen. Der Prototyp ist hier erreichbar. In Zukunft wird die Anwendung bei Bremen de integriert und dort verfügbar sein.

Am Donnerstag sind wir bei strahlendem Sonnenschein mit Tablets einen der Spaziergänge abgelaufen. Wir haben uns angeschaut, was gut und was nicht gut funktioniert, wann und wo weiche Informationen relevant sind und weiche Daten fehlen. Dabei konnten wir einige Schwachstellen identifizieren. Zum Abschluss haben wir bei einem Mittagessen die Anwendung diskutiert. Die Ruckmeldung unserer Teilnehmer'innen und Tellnehmer war Uberwiegend positiv. Nach Fertigstellen der Anwendung und der Obernahme durch Bremen.de soll ein weiterer Nutzertest mit externen Nutzerinnen und Nutzern abschlieBend die Usability der Anwendung evaluieren.

\section{Bilder / Fotos}

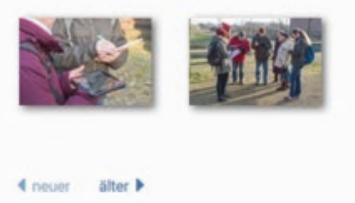

Ihr Kommentar

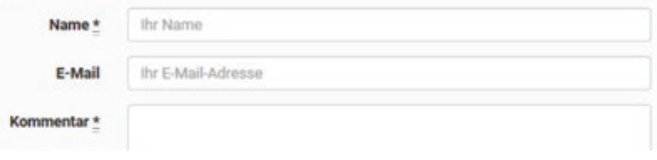

Fig. 6 The project blog

Table 7 Lessons learned for co-creation a service concept in the second co-creation project

\begin{tabular}{l|l|l}
\hline & Lessons learned derived from Osterholz & $\begin{array}{l}\text { Actions to be implemented in second } \\
\text { co-creation project }\end{array}$ \\
\hline $\begin{array}{l}\text { Co-creating } \\
\text { a service }\end{array}$ & $\begin{array}{l}\text { O-3.1: Consider methods that connect } \\
\text { different activities and relate to defining } \\
\text { characteristics of the target group }\end{array}$ & $\begin{array}{l}\text { Use methods that connect different } \\
\text { activities and allow for the refinement } \\
\text { of the target user groups }\end{array}$ \\
\cline { 2 - 3 } $\begin{array}{l}\text { O-3.2: Consider intermediaries as main } \\
\text { users of a service }\end{array}$ & $\begin{array}{l}\text { Identify intermediaries, such as service } \\
\text { and care providers and investigate how } \\
\text { a digital service could support their } \\
\text { work }\end{array}$ \\
\cline { 2 - 3 } & $\begin{array}{l}\text { O-3.3: Consider a service that is more } \\
\text { activating/beyond information provision }\end{array}$ & $\begin{array}{l}\text { Identify and implement potential } \\
\text { services that could complement the } \\
\text { information provided in a digital } \\
\text { district guide }\end{array}$ \\
\hline
\end{tabular}




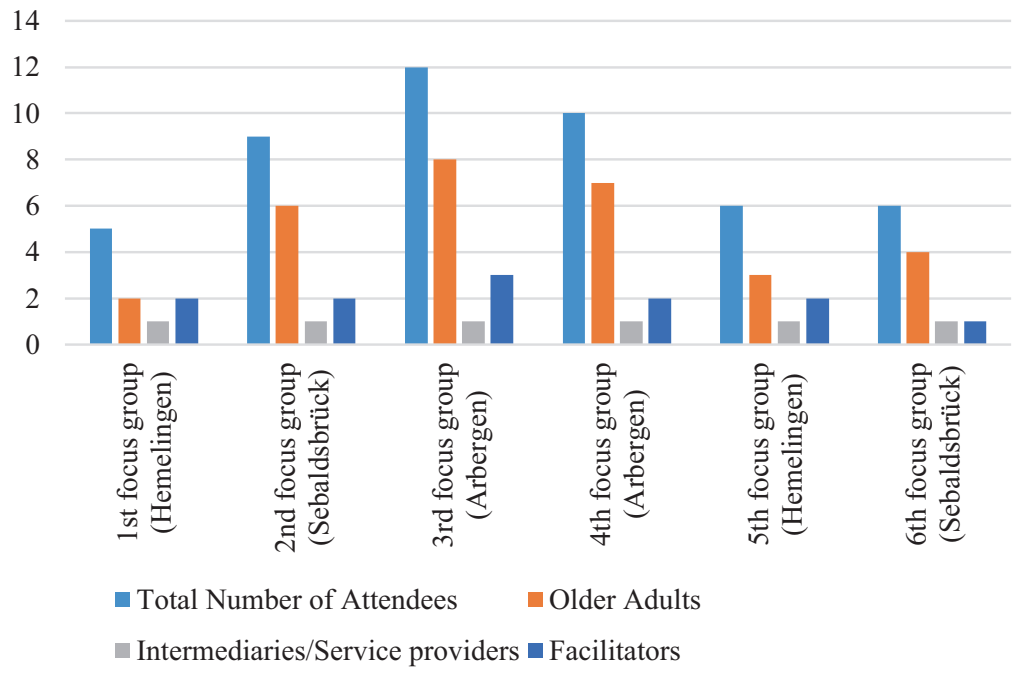

Fig. 7 Number of stakeholders in focus groups

different neighbourhoods in the district. One group consisted of older adults that regularly participate in activities from the community centre of the Protestant church. The second focus group was conducted with a group of people with mental health problems. The third group was a group of people from a resident home for older adults. However, the last two groups could not be engaged in the further process (Fig. 7).

We had learned from the first co-creation project, that one needed to have an idea of the thematic space of the service, the target user group(s) and the kind of technical solution that is going to be developed (mobile app, website). Since we had planned to co-create a digital district guide similar to one from our first co-creation project, we took this service as a starting point for the development of a refined service concept. Hence, in the first round of focus groups our intended goal was to get feedback on the Osterholz service and to detail a rough service concept for Hemelingen. We presented the project and completed the consent forms. We talked about where participants get information about the district and showed the digital district guide from Osterholz and discussed it. We worked with printed screenshots of the district guide in order not to alienate people that may feel intimidated by using a tablet. The focus was on the content, and we worked on the following tasks

- Are the categories on the front page the important topics? What is missing?

- Is the content under each topic what you expected it to be? What is missing?

- Are the attributes appropriate to describe the places in the respective category?

- Are the information relevant at all? Can you find them somewhere else?

We further discussed relevant topics in the district for older adults and handed out a reduced set of cultural probes. In two of the focus groups, we got positive 
feedback on the Osterholz district guide. In the elderly care home however, it became apparent that a district guide was not of relevance for the residents. Most of them suffered from health-related mobility restrictions and had much more basic needs than the kind of service we planned to develop could respond to (e.g. better access to public transport).

In the second round of focus groups, we worked with the printed district guide and discussed in what ways a digital district guide could enhance/complement the service in an activating way. In parallel, we had discussed the question with project board. Both stakeholder groups, service providers and older adults, emphasized the issue of segregation and the lack of a mutual identity inside the district. In addition, the social activities manager of the community centre of the Protestant church reported on a strong interest amongst older residents for joint district walks.

We determined with our participants in the focus groups as well as in agreement with the project board to focus on district walks. The concept we developed was a digital walking guide for the district. It had to contain activating elements that motivate older adults to go outside, to meet others and to explore other neighbourhoods. Furthermore, it should support the service providers to organise and conduct these kind of activities.

Probes In order to make the probes more feasible (O-1.3), we cut down on the probes pack. We did this by adapting the initial set of probes from the first phase. Instead of a daily diary, we included a more standardised questionnaire. The aim was not so much to understand the everyday life of participant but rather to gather data on them, their relation to the district and their experiences and skills with digital technologies. We kept the map of the district.

In the following I report on our negative experiences with using these reduced probes with a group of six residents of a care home, all aged above 79 years.

In an initial workshop, we introduced the project and discussed about the information needs and interests of the group. All, but one of the participants were active users of mobile devices, such as tablets and members of a "tablet group" which meets regularly. During this initial workshop we handed out the probes bags to each of the participants. In a workshop scheduled two weeks later, we agreed to collect them again.

In contrast to the experiences we made in Bremen Osterholz, this group did not appreciate the probes at all. One participant spoke of a "shock bag". We had the opportunity to discuss with the participants about their experience in the workshop (after which they jointly decided not to participate in the project anymore) as well as separately with the director of the residence home.

The reasons for the rejection of the probes may be manifold, but I would like to concentrate on two here: (1) the tasks were not appropriate for the participants and (2) by trying to complete the tasks, participants were not established as experts but rather were identifying their own limitations and perceived deficits. The first point relates to the map, which was not well to read. This experience was reported as being frustrating for the participants who subsequently questioned either their own 
ability to fulfil the task as well as our good intentions in posing such a difficult task in the first place. The second point relates to our focus on movement patterns, sociospatial networks and knowledge about the district which did not fit well with the participants' abilities and interests: since many of them had mobility impairments, questions relating to their movement patterns made them even more aware of their limitations. Moreover, since most of them had only recently moved to the district (into a residence home) they neither had many social relations nor comprehensive knowledge about the district. Participants justifiably questioned how well we had anticipated and understood their particular situation.

In our striving to develop sets of probes that may be used in other co-creation contexts also focussing on space-related issues concerning ageing (e.g. ageing in place), we only slightly adapted the probes from our first process. However, we had to realise that in order to develop meaningful and engaging probes, a much more substantial engagement with the specific circumstances of participants needs to take place. Sadly here, the probes did not establish participants as experts of their everyday life and ageing in a neighbourhood, but rather highlighted their increased immobility and age-related deficits.

In sum: In contrast to Osterholz, we agreed to co-create a digital district map with a specific focus on neighbourhood walks (O-4.2). In addition to simply providing information about possible walks/routes, we planned to include (1) activating functionalities (e.g., to organise and/or participate in social activities via online tools - O-3.3) and (2) to support elderly care and support providers to organise inclusive activities for older adults (O-3.2)

\section{Working with (Open) Data: Data Walks and Content Creation}

There were three lessons learned derived from our co-creation project in Osterholz that were relevant to the working with (open) data in Hemelingen. The actions to be taken in Hemelingen are outlined below (Table 8).

\section{Data Walks}

\section{Step 1: Detailing the service idea for digital walks}

In order to detail the concept for a digital service and define the data (categories), a first walking workshop was conducted in June 2017 together with a social activity manager of a senior citizen centre. The participants were recruited through the staff of the senior citizen centre but also via newspaper announcements. Most participants could walk without support, few had walking aides. The intended goal was to identify relevant attributes for walking routes (what information older adults need or are interested in on walking routes). In addition, the aim was to raise interest in the project so that participants would become engaged throughout the process. 
Table 8 Lessons learned for working with (open) data in the second co-creation project

\begin{tabular}{l|l|l}
\hline & $\begin{array}{l}\text { Lessons learned derived from } \\
\text { Osterholz }\end{array}$ & $\begin{array}{l}\text { Actions to be implemented in second } \\
\text { co-creation project }\end{array}$ \\
\hline $\begin{array}{l}\text { Co-creating } \\
\text { (open) data }\end{array}$ & $\begin{array}{l}\text { O-4.1: Take into account that } \\
\text { information identified as } \\
\text { relevant may not be available as } \\
\text { open data }\end{array}$ & $\begin{array}{l}\text { Plan ahead to collaborate with various data } \\
\text { owners (e.g. service providers) and allow } \\
\text { sufficient time for data creation during the } \\
\text { co-creation process. } \\
\text { Offer a user-friendly backend for inputting data } \\
\text { to participants }\end{array}$ \\
\hline & $\begin{array}{l}\text { O-4.2: Less is more. } \\
\text { Concentrate on a few categories } \\
\text { of objects }\end{array}$ & $\begin{array}{l}\text { Identify and concentrate on a manageable } \\
\text { number of categories of objects (in line with } \\
\text { the human resources available and involved in } \\
\text { the co-creation process) }\end{array}$ \\
\cline { 2 - 3 } & $\begin{array}{l}\text { O-4.3: Consider methods for } \\
\text { "snowball" data collection }\end{array}$ & $\begin{array}{l}\text { Use methods that allow a variety of older adults } \\
\text { to contribute to the data collection }\end{array}$ \\
\hline
\end{tabular}

The route had been defined in a preceding meeting with the project board. The announcements in the newspapers foregrounded the joint walk through the neighbourhood rather than the technology focus of the project itself, in order to keep the barriers for participation low. It was planned to walk together along the route and complete a questionnaire on what attributes may be considered relevant (Fig. 8).

The questionnaire had been developed based on literature on accessible and agefriendly neighbourhoods and cities by the team facilitating the project. It asked the participants 'to mark what you think is important for the description of walks and paths and make notes if you have discovered something accordingly on the way' and offer response items in the following areas:

- Points of interest (Architecture/buildings, historical, green areas, art, other)

- Helpful things (benches, restrooms, railing/handrails, street greening (shade), illumination, other)

- Useful things (shops, services, sport, playgrounds, other)

- Rest points/provision of food and drinks (cafés, restaurants, kiosk, bars, other)

- Sidewalks (Inclination/longitudinal and/or transverse inclinations, narrow places, separation of footpaths and cycle paths, obstacles, breadth, height of the curb, cleanness, surface condition, other)

- Road crossing/unavoidable road use (traffic light available, traffic island available, lowered curb, surface of the road to be crossed

- Size (lanes/tracks) of the road, traffic intensity, pace, other)

- Annoying things (dog excrement, dirt/waste, noise, smell, cyclists on footpaths, other)

- Public transport stops (shelter, other)

Nine older residents from the district participated in the first walk. Most of them had lived there for a long time and were very knowledgeable about it. For example, they talked about the historical developments in the district, which turned out to be a main point of interest for walks. 

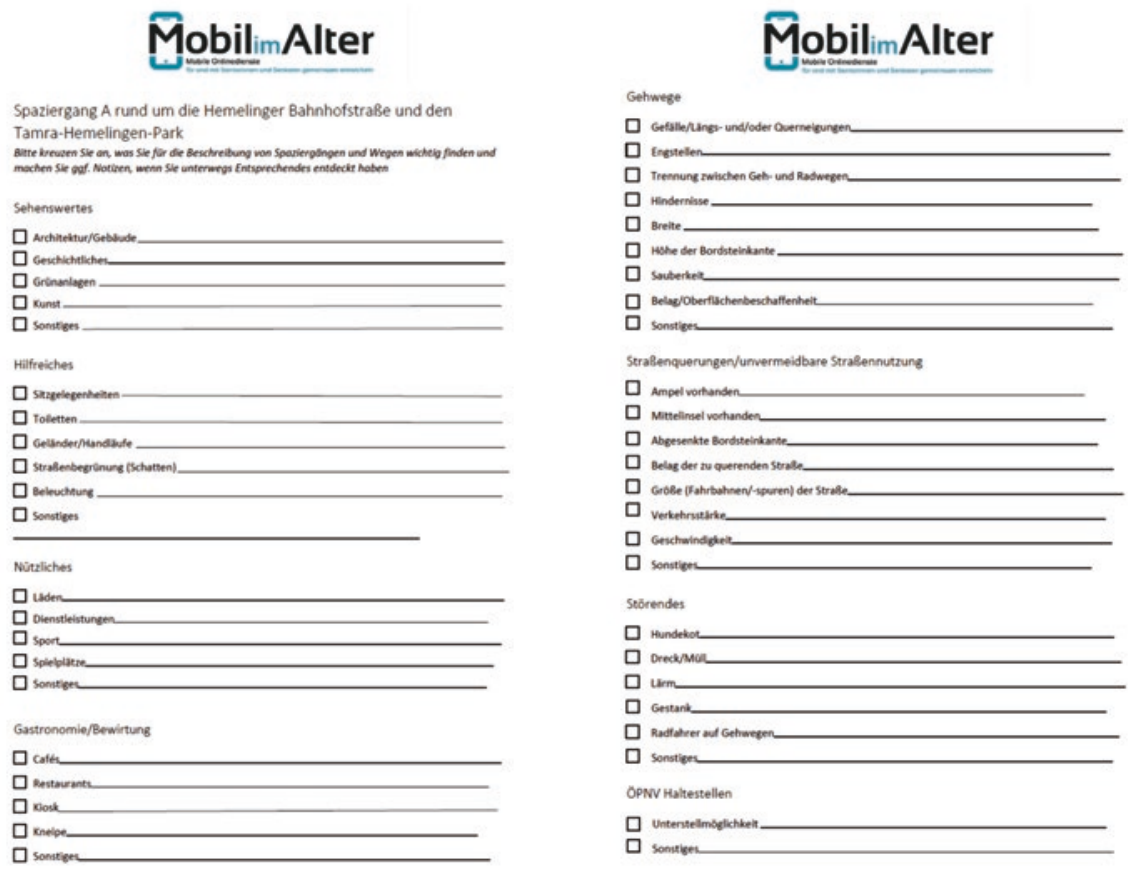

Fig. 8 The questionnaire on attributes for describing walking routes

The analysis of the questionnaire confirmed the impression that the participants were more interested in historical and recreational attributes than in information on accessibility. Five participants were interested in architecture and buildings; four were interested in historical information. Six were interested in recreational spaces. While seven stated to appreciate information on benches and toilets, only three were interested in information about traffic lights and almost none listed any of the attributes concerning the pavement and the road crossing. In a subsequent focus group, which was meant as a debrief of the results, it became apparent that, in addition to the accessibility of walks, a thematic focus of the digital walking guide on historical and recreational walks was commended.

The results of this first walk confronted us with the recognition that the data required to realise this service idea were not available. We had expected that the target group would be particularly interested in the accessibility of routes and buildings, public transport, benches, toilets, restaurants and other practical aspects, on which open data sets are (easily) available. However, we quickly realised that the required information on the history of and stories about the district as well as tips about recreational places (e.g. for walking) was not available: All of the participants had their personal stories to tell which revealed surprising and interesting facts 


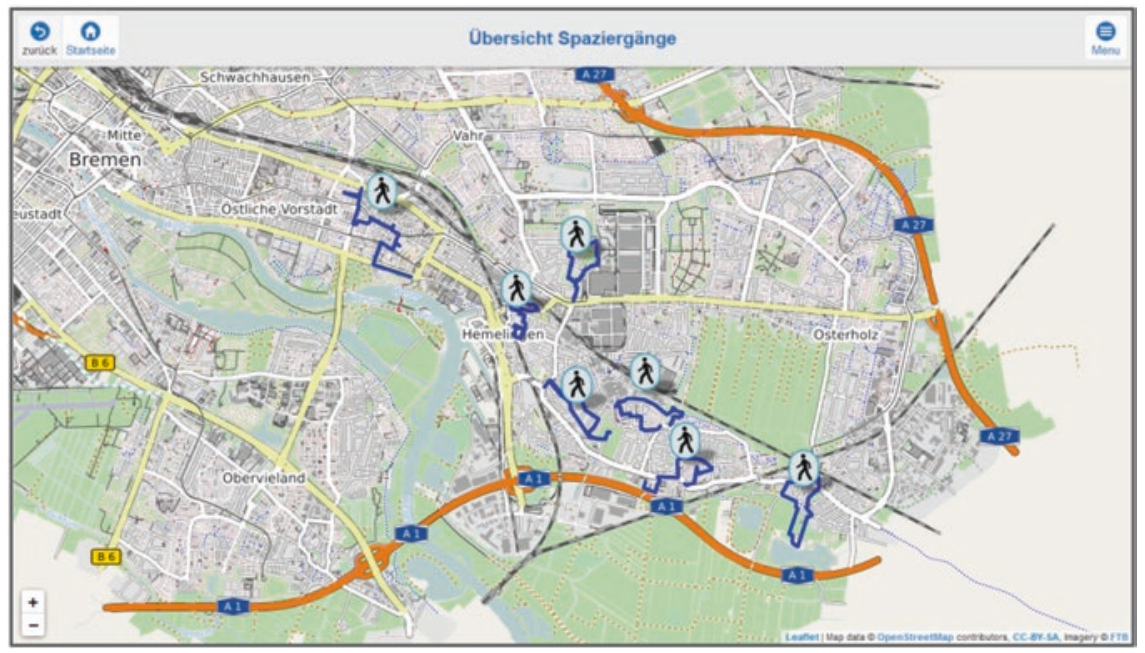

Fig. 9 Map with the routes of the neighbourhood walks

about the historical development of the neighbourhood. Some of them knew places unknown to the others they wanted to share. In order to collect this local knowledge and make it available via a digital service to a broad range of older adults in the district, we started conducting data co-creation walks.

\section{Step 2: Conducting data co-creation walks}

In a second step, we conducted walks to engage further residents and co-create data on these walks. They differed in their scope and framing:

- Walks in parks and recreational areas (walks 1-4)

The walks were conducted in collaboration with the senior citizen meeting place in one of the neighbourhoods.

- Guided historical walks (walks 5-6)

We conducted two walks that were each organised by an older resident that talked about the neighbourhoods' history.

The figure below provides an overview on the walks, that we co-created (Fig. 9).

Each walk was announced via the local newspapers, the district's website as well as the network of service providers. They were between 2 and $3 \mathrm{~km}$ and lasted between $90 \mathrm{~min}$ and $2 \mathrm{~h}$. This time was proposed by the network of service providers (project board) as most suitable (also for people with mobility issues) and included time for breaks. The starting points were well-known places in the district and reachable by public transport. Each of the walks included at least one stop for either lunch or cake and coffee. The descriptions of the walks featured places with lunch offers for older adults or coffee and cake as well as public toilets and benches. Figure 10 presents an overview of the different participant groups participating in the walks. Figure 11 shows how participants took notes during the walks. 


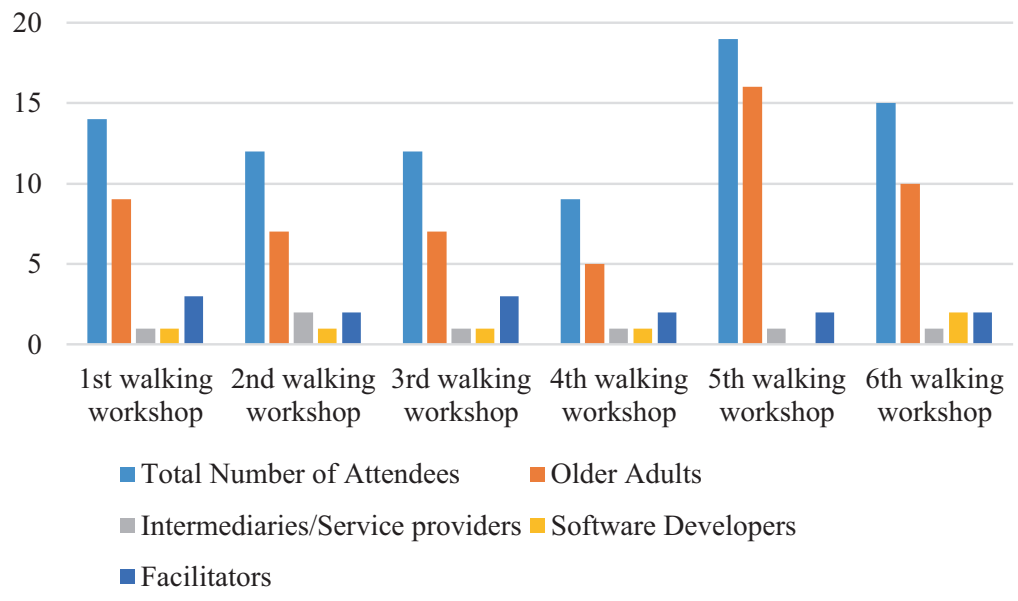

Fig. 10 Number of participants per stakeholder group in walking workshops

Fig. 11 Note-taking during our walks

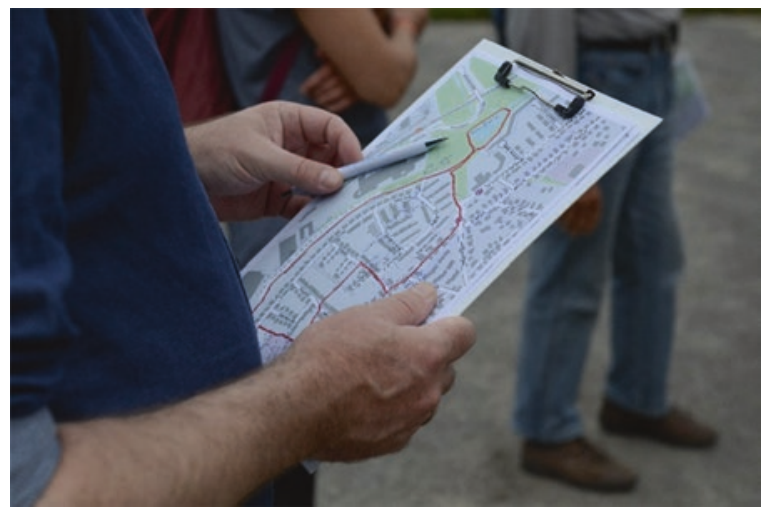

The older participants and service providers assumed different roles in the walks which are summarised in the following table (Table 9).

During the walks, a central topic that the participants discussed was the agefriendliness of the urban infrastructure. Part of the discussion on the walks was voice recorded, valuable data on problems about and with the physical infrastructure were collected. Subsequently, the data was presented during one of the district council meetings in order to suggest improvements (e.g. installing new benches). The data collected on the walks was then used to co-create a walking guide that visualises the routes and provides relevant information as well as appealing multimedia content that is meant to motivate older adults to explore their district jointly. In order to do so, a number of design workshops were conducted in which participant produced multi-media content. 
Table 9 Roles assumed by co-creators during walks

\begin{tabular}{l|l}
\hline Role & Description \\
\hline Organiser & $\begin{array}{l}\text { One of the local social care service provider acted as organiser of the walks. } \\
\text { They published the announcement in their networks and newspapers and also } \\
\text { organised with other service providers for visits during lunch time or for coffee } \\
\text { and cake }\end{array}$ \\
\hline Guide & $\begin{array}{l}\text { The tours were either guided by knowledgeable residents on historical points } \\
\text { of interest or planned as walks through parks and recreational areas }\end{array}$ \\
\hline Data collector & $\begin{array}{l}\text { Most participants on the walks used a clipboard to note down points of } \\
\text { interest, issues with the infrastructure (e.g. missing benches) and other } \\
\text { noteworthy things }\end{array}$ \\
\hline Photographer & $\begin{array}{l}\text { One of our participants checked the location of benches on the walks as } \\
\text { provided by OpenStreetMap. If benches were missing on OSM, he added } \\
\text { them; if benches were listed on OSM but not existent, they were deleted }\end{array}$ \\
$\begin{array}{l}\text { Overall, three older adults participated supported our data collection by taking } \\
\text { pictures. Not all pictures could be taken during one of the walk, so all of them } \\
\text { volunteered to visit points of interest again }\end{array}$ \\
\hline
\end{tabular}

\section{Step 3: User Testing}

In order to review the functionality of the app, which was developed in subsequent workshops and the quality of the data, a last walk was conducted where participants tested the application on tablets. They were asked to review and discuss the functionalities, the relevance of the content and the quality of the data. This led to a number of usability and functional issues that had to be resolved. In a subsequent focus group, we asked for further feedback. The participants emphasised that they were happy to see the progress of the app, the contents and their own contribution to it.

\section{Summary: Phases 1-3}

Overall, the walkshops conducted helped us define and refine a service concept, cocreate data and test the digital service developed. Participants in those walking workshops assumed a number of different roles, from explorer (what kind of walks are of interest to other older adults), to idea former (what kind of information may be of interest to others), to data creators and validators, users and testers of digital apps.

\section{Content Creation Workshops}

In addition to the individual walks in Bremen Hemelingen that we ran a series of eight content creation workshops in order to (1) recruit older adults, (2) demonstrate the interest of older residents in such walks and (3) collect data (and produce digital content for the digital district guide). These content creation workshops were supported by accompanying tablet support groups for those older adults which were not familiar with digital technologies. 
Overall we conducted 11 workshops dedicated to either content co-creation (8) or software co-creation (3). We called them all "tablet workshops" as we were working with tablets and it did not matter to the participants to distinguish between the two types of activities. There was generally a good attendance with an average of four to five participants.

\section{Using a Content Management System ${ }^{3}$}

Our core group consisted of five male and two female participants with varying technology skills and knowledge about the district. In those workshops (and the times between meetings), participants described the walks according to the attributes/templates defined under the service concept. Participants had access to a tailor-made back-end in order to provide these descriptions and information to the system (Fig. 12).
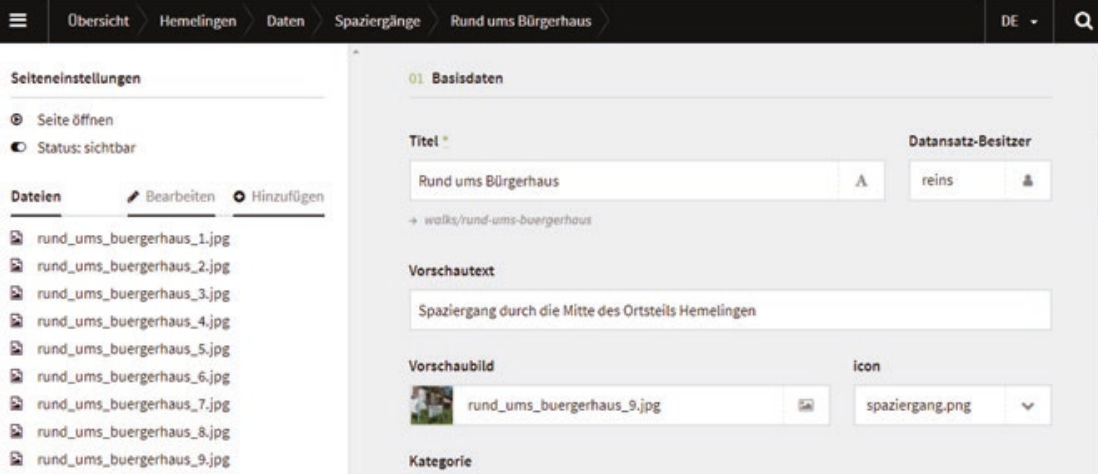

Spaziergang durch die Mitte des Ortsteils Hemelingen

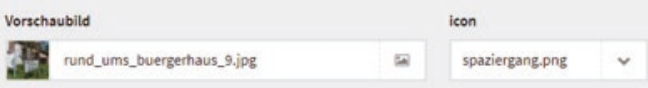

Kategorie

D. Naherholung

Distorisch

nächster Termin

năchster Spaziergang Uhrzeit Informationen zum Termin

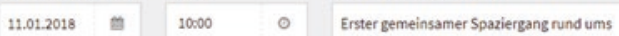

Bürgerhaus Hemelingen mit Testnutzung der

Anwendung. Treffpunkt ist die evangelische

Begegnungssatte in der Christemstrabe 6.

Daver ca. 3 Stunden

E-Mail Telefon

Karin Schüdde

Name des Organingtion

Speichern

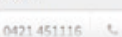

Fig. 12 Screenshot of the data backend for a walk

${ }^{3}$ This system was set-up by our Mobile Age partner FTB. 
After the very rudimentary and pragmatic data creation support in the first cocreation project in Osterholz, a more user-friendly backend for the second cocreation project was desired. For Hemelingen, a content management system (CMS) handled the data co-creation of the participants. A location database was manually initialised with the data provided by the printed "Stadtteilplan für ältere Menschen Hemelingen" and then maintained and improved by the participants of the co-creation workshops.

\section{Creating Screenplays and Producing Multimedia Slideshows}

In addition, participants produced short videos about the walks in order to raise interest in the walks. Originally, we had thought that the information gathered on the walks and from participants could easily be used for video and audio clips attached to each walk. However, participants had difficulties to do so from a userperspective. In order to enable participants to shift their perspective from reporting their own experience to creating motivating videos that make other people feel like wanting to experience the walks, we recognised the need to develop scripts for multimedia screenplays, storylines of what the highlights of the walks are, and a corresponding video sequence and corresponding comments on the voice track. This did not only require a new conceptual perspective but also different software tools for slide show creation. We used a video editing app on the tablets.

Most of the produced videos are slideshows of photographs and include a spoken text by participants. The reasons for producing videos were (1) to create content for the digital neighbourhood guide, (2) to expose participants to (new) software, and (3) to allow older adults who do not feel comfortable in writing long texts to contribute orally. As we had experienced in Osterholz that not all participants felt comfortable and competent to write. Others did not feel competent to create slide shows on the tablets. In Hemelingen, the different participants with their respective preferences and abilities could take over different roles and complete different tasks according to their competencies and interests. This was considered a more inclusive practice. For parts of the descriptions, where we did not have written text, we used transcripts of the videos.

The picture below shows a participant checking the route on a printed map while working on the slide show, confirming where the picture on his tablet was taken (Fig. 13).

\section{Detailed Information About a Walk}

The detailed information page about a walk displays all relevant information stored for the walk. The information about walks contains:

- The title of the walk.

- A short description.

- The length of the walk.

- The estimated duration.

- A small image for decoration.

- A long description of the walk.

- A video clip if available. 


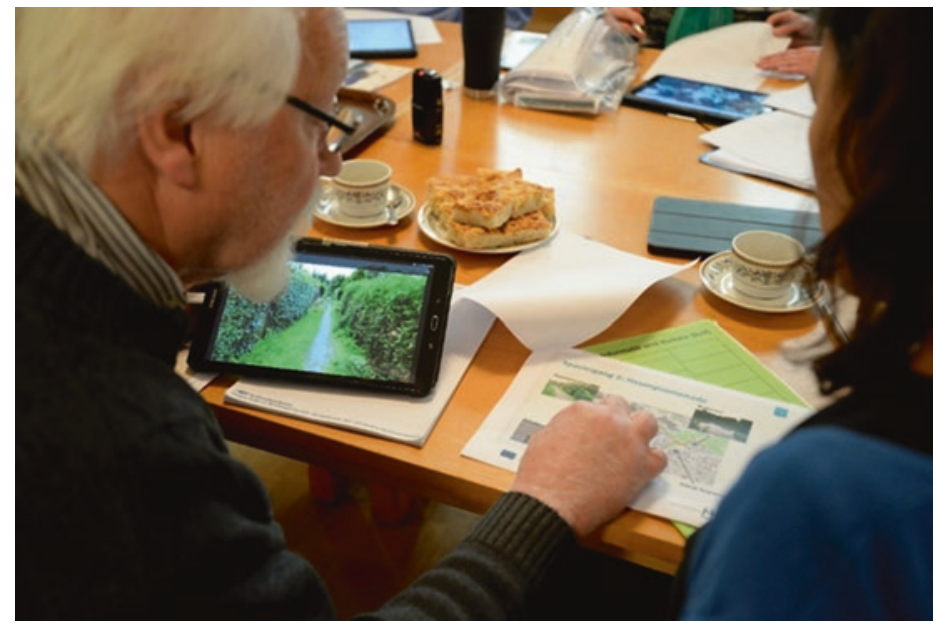

Fig. 13 Producing a slideshow while checking the route

- An image gallery with a list of previews of all available photos.

- Information on availability of toilets, benches, street lightning and hospitality services along the route.

\section{Detailed Information About a Location}

In addition to information about the walks, participants also produced information about points of interest. The information about a location contains:

- The title of the location.

- A short description.

- The relevant categories of the location.

- A long description of the location.

- The address of the location if available or a description of where to find the place, if the place is a bigger area.

- A video clip, if available.

- An image gallery with a list of previews of all available photos.

- Keywords that Give a Brief Description of the Available Offers and Services.

- Information on how to get to the location by public transport

- Information about the accessibility of the location.

- Further important information.

- A block of contact information, like contact person, telephone number, email, homepage, sponsorship/owner and opening hours.

The data and information provided by the application was mainly produced by older adults who participated in the co-creation project. Some of the co-creation participants were able to use the app's database backend to feed in the collected data. The user-friendly backend was used for input and maintenance of structured data about the walks and the locations at the walks. 
Table 10 Lessons learned for co-creating software in the second co-creation project

\begin{tabular}{l|l|l}
\hline & $\begin{array}{l}\text { Lessons learned derived from } \\
\text { Osterholz }\end{array}$ & $\begin{array}{l}\text { Actions to be implemented in second } \\
\text { co-creation project }\end{array}$ \\
\hline $\begin{array}{l}\text { Co-creating } \\
\text { software }\end{array}$ & $\begin{array}{l}\text { O-5.1: Consider the reduction of } \\
\text { prototyping tasks }\end{array}$ & $\begin{array}{l}\text { Devote specific sessions to prototyping and } \\
\text { only involve those older adults interested. } \\
\text { Establish procedures to feed the continuous } \\
\text { development back to participants }\end{array}$ \\
\cline { 2 - 3 } & $\begin{array}{l}\text { O-5.2: Consider design of } \\
\text { application beyond design of user } \\
\text { interface }\end{array}$ & $\begin{array}{l}\text { Consider design of data structures and } \\
\text { back-end functionality for data } \\
\text { maintenance }\end{array}$ \\
\hline
\end{tabular}

Some basic information was provided with permission of the media agency producing district guides for older adults. Further information was provided with permission of different providers (e.g. data on street lightening). The data sets were substantially supplemented by the participants of the co-creation workshops, with very detailed information, new walking routes, new locations, photos and video clips. Information about public toilets and benches/seats were retrieved from the German OpenStreetMap community, ${ }^{4}$ for which one of the co-creation participants checked all public toilets and added the address information and opening hours.

\section{Co-creating Software ${ }^{5}$}

There were two lessons learned concerning the co-creation of software which we considered for our second co-creation project. The actions to be implemented are outlined in the table below (Table 10).

Based on lesson learned O-5.1, we decided to cut-down on the (paper) prototyping tasks and use digital prototyping sessions (and feedback sessions) to further advance our demonstrator. In total, we ran three prototyping workshops.

At the beginning of the content creation phase, we conducted one workshop in which we broadly defined the visualisation and functionality of walks. Rather than working in smaller groups, we had an open discussion with an oversized display on a pin board (Fig. 14). The Osterholz demonstrator served as a point of reference. The definition of attributes as developed during the walking workshops served to structure the information screens (Fig. 15).

In order to review (1) the functionality of the app and (2) the quality of the data we walked along one of the walks in the neighbourhood Hemelingen while using

\footnotetext{
${ }^{4} \mathrm{https}: / /$ www.openstreetmap.de/.

${ }^{5}$ The software development and design work in this co-creation stream was led by our Mobile Age partner FTB.
} 


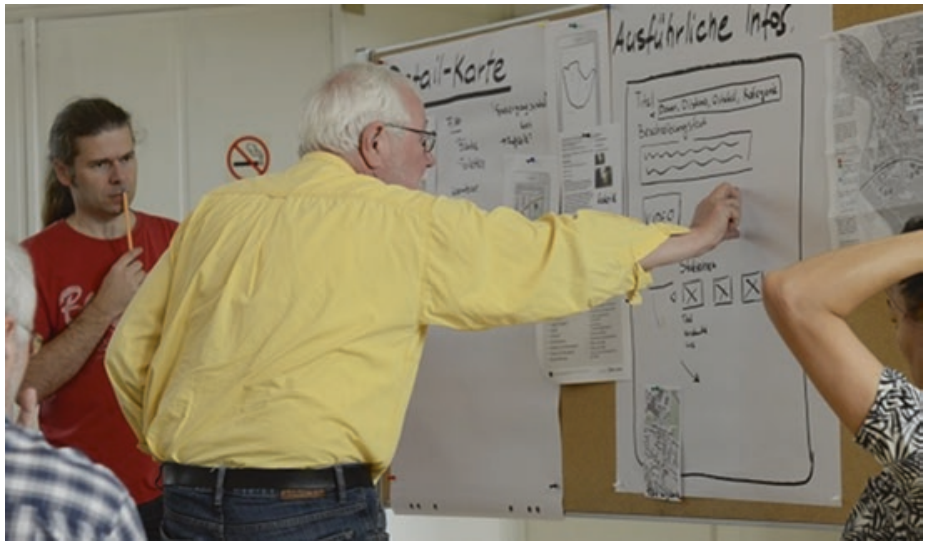

Fig. 14 Discussing the design of the digital neighbourhood guide

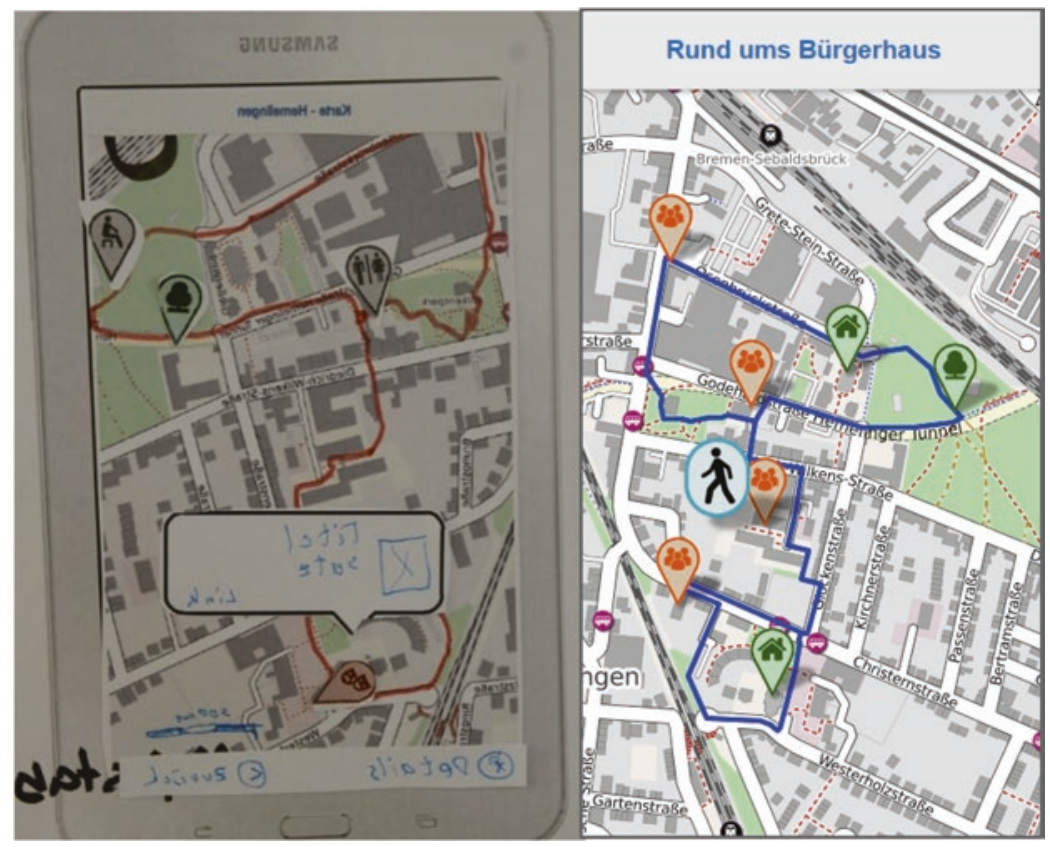

Fig. 15 Paper prototype and zoomed in map with the route of a single walk. Pins are displayed for every location along the walk

the application on tablets. We asked participants to review the functionalities, the relevance of the content and the quality of the data. At a coffee break in between and a closing lunch, we discussed the feedback in the group. We observed the participants while using the app, took notes and audio-recorded the discussions. 


\section{Exploiting and Disseminating the Service}

The main challenge and lesson learned from Osterholz in this stream of activity was that the sustainability of the service remains a big challenge (Table 11).

\section{Dissemination and Communication of the Co-creation Process and Service}

As we had learned from Osterholz that local newspapers are the most effective medium to reach our target group, we aimed at disseminating our activities in Hemelingen as best as possible via this channel. Since the district of Hemelingen is covered by the same newspaper supplement as Osterholz, we could use our contacts to journalists from two local newspapers. Before we started the co-creation activities in Hemelingen our aim was to raise awareness for the project in this district. According to our strategy not only to involve older adults, we wanted to make the project visible amongst older adults as well as intermediaries, service providers and members of the local government. In order to gain support from the local administration we organised a kick-off event in May 2017, were we invited the press.

During the kick-off event, we informed about the activities in Bremen Hemelingen and stated that we were looking for more collaborators in the core group. We also presented the results from our activities in Bremen Osterholz on a multi-touch table (see Fig. 16). The event was well attended with the head of local district government, the district marketing, representatives of the district council, two service providers from the network "Alte Vielfalt" and a neighbourhood manager.

At the local summer fair in Osterholz in May 2017, we presented the Osterholz app on a multi-touch table. Since the fair was also visited by many Hemelingen residents, we used this dissemination event of the results from Osterholz simultaneously for the recruitment of co-creators for Hemelingen. Several important actors from Hemelingen were there and we could raise interest and commitment amongst them through showing the results from Osterholz.

Through these two events we gained some public attention and the two local newspapers reported about the project and it's continuation in Bremen Hemelingen several times. Since our recruitment strategy to engage existing groups of older people through the service providers and intermediaries of our project board, did not work as well as expected, we used the press coverage to announce our activities. In particular, we wanted to attract a broad range of older residents in Hemelingen for the walking workshops.

Table 11 Lessons learned for exploiting and disseminating in the second co-creation process

\begin{tabular}{l|l}
\hline $\begin{array}{l}\text { Lessons learned derived } \\
\text { from Osterholz }\end{array}$ & Actions to be implemented in second co-creation project \\
\hline $\begin{array}{l}\text { O-6.1: Sustainability } \\
\text { remains a big challenge }\end{array}$ & $\begin{array}{l}\text { Identify local stakeholders that can sustain the maintenance of the } \\
\text { service early in the process (e.g. identify ways in which the service } \\
\text { serves their interests/supports their work) }\end{array}$ \\
\hline
\end{tabular}



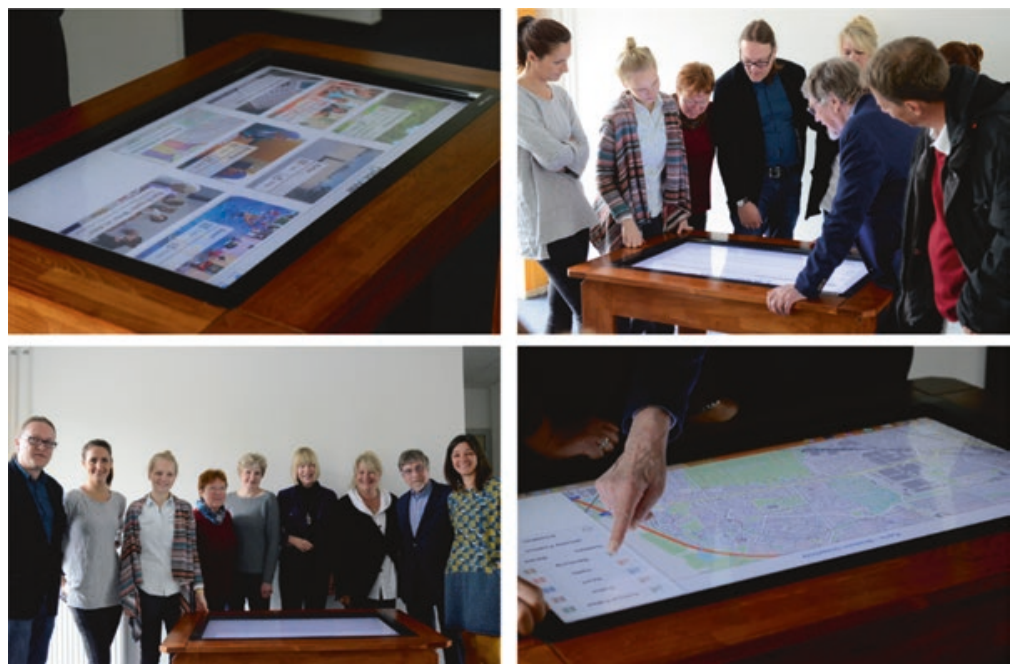

Fig. 16 Meeting with local stakeholders in Hemelingen to present results from Osterholz on a multi-touch table

During the process, the newspapers reported on some of the conducted walks and simultaneously announced the next ones. We thereby reached a broad range of people that participated in the walks. In addition, the collaborating service providers announced our walks and tablet groups in their communication material. This led to quite a high number of participants in some of the walks. However, often a large number of the participants only showed up for one walk. Furthermore, our engagement with the project board opened up some other dissemination channels for us. The director of the district marketing invited us also to announce the walks on the event calendar on the website of the district marketing and she published an article in the annual magazine of the district.

\section{Sustainability}

As in the case of Bremen Osterholz, sustainability of the co-created demonstrator was achieved by the migration to the official city information provider bremen. online. Most crucial for the sustainability of a digital service is to keep the information offered up to date. As most of the data from Hemelingen had been generated by the participants there was no possibility for automatic updates and linked open data (as in Osterholz). On the other hand the attributes of the point of interest do not change very frequently. Therefore, the members of our project board and the "Alte Vielfalt" committed themselves to maintain the information on one walk each.

Similar to Bremen Osterholz, I provide below a canvas of the final co-created service (Fig. 17). 


\begin{tabular}{|c|c|c|c|c|}
\hline \multirow{2}{*}{$\begin{array}{l}\text { Key partners } \\
\text { - network "Alte } \\
\text { Vielfalt" } \\
\text { - neighbourhood } \\
\text { managers } \\
\text { - other service } \\
\text { providers and } \\
\text { intermediaries }\end{array}$} & \begin{tabular}{c|c} 
Key activities & \\
Review and update & \\
information \\
Conduct walks \\
Provide tablet \\
classes
\end{tabular} & \multirow{2}{*}{$\begin{array}{l}\text { Value } \\
\text { proposition } \\
\text { service that } \\
\text { provides relevant } \\
\text { and appealing } \\
\text { information to } \\
\text { older adults which } \\
\text { motivates joint } \\
\text { walks and supports } \\
\text { service providers in } \\
\text { organising and } \\
\text { announcing these } \\
\text { kinds of walks }\end{array}$} & $\begin{array}{l}\text { Relationship } \\
\text { ageing-in-place }\end{array}$ & \multirow{2}{*}{$\begin{array}{l}\text { Target audience } \\
\text { Older residents in } \\
\text { Bremen Osterholz }\end{array}$} \\
\hline & $\begin{array}{l}\text { Key resources } \\
\text { Existing networks } \\
\& \text { collaborations; } \\
\text { Existing services } \\
\text { and information } \\
\text { about services }\end{array}$ & & $\begin{array}{l}\text { Channels } \\
\text { online \& print }\end{array}$ & \\
\hline \multicolumn{2}{|c|}{$\begin{array}{c}\text { Cost structure } \\
\text { No costs for web space } \& \text { hosting } \\
\text { Checking data is up-to-date on a yearly basis } \\
\text { (2 person days) }\end{array}$} & \multicolumn{3}{|c|}{$\begin{array}{c}\text { Revenue Stream } \\
\text { Premium entry for commercial organisations } \\
\text { (free for NGOs) } \\
\text { Online advertisements on welcome page (e.g. via banner) } \\
\text { Provide template and methdology to other districts }\end{array}$} \\
\hline
\end{tabular}

Fig. 17 Final canvas for co-created service in Bremen Hemelingen

Table 12 Overview of activities/methods deployed in Bremen Hemelingen from May 2017 to February 2018

\begin{tabular}{l|l}
\hline Activity type & Number of activities \\
\hline Cooperation meeting & 2 \\
\hline Dissemination event & 2 \\
\hline Tablet workshop & 11 \\
\hline $\begin{array}{l}\text { Stakeholder meeting (meetings with project } \\
\text { board) }\end{array}$ & 8 \\
\hline Data collection & 2 \\
\hline Walking workshop & 7 \\
\hline Focus group & 8 \\
\hline
\end{tabular}

\section{Summary of Co-creation Process and Output}

As in Osterholz, there was an emphasis on activities in the engagement with stakeholders, the co-creation of a service concept and the working with data. In contrast to Osterholz the co-creation of software took less time and space. Below, I provide an overview of the activities we used during our co-creation process (Table 12).

There are three kinds of output of the co-creation process of the interactive digital district guide for Bremen-Hemelingen:

- data collected and presented in the guide,

- an app providing access to these data,

- an online service in which data and app are embedded. 
As it has been described above, the guide contains seven neighbourhood walks. A social activities manager emphasised the special appeal of the multimedia information in an interview:

I also find it simply well turned out optically, with these word contributions or with the small videos, which are inserted and where then you can see the walks and the people, who were there, that I find already beautiful.

\section{Value for Older Adults}

All stakeholders assess the service as being relevant to older users. The overall relevance for this particular target group is seen in the relevance of walking for older adults. As the social activities manager says, that "going for a walk is much more part of the reality of older adults than of younger generations". And the director of the association for social work (MoBiLe) adds the dimension of retirement:

I believe that $[\ldots]$ for other people who already live here, but maybe have always worked, always had a family around them and maybe are now in a situation that they now also have time to do a bike tour or something.

In addition to the overall relevance of walks for older adults, the service providers, intermediaries and participants define the value of the service for particular groups of older adults. Most of the stakeholders emphasised the value of the walking guide for older people who are not well oriented in the district. This applies for example to many of the new residents in elderly care homes and residents. The director of association for social work (MoBiLe) stated

With such a portal you reach the people who are still fit, who can still walk, but they are also important to reach, right? Because these are often those who can still walk, but have no more ideas.

Also the social activities manager confirmed the motivational effect of the app and added that the service can help older people to find their way when walking:

Well I think that the people who want to know, they will certainly orient themselves to it. [...] And I think in this regard it is an excellent thing to get people moving again, because then maybe they know again, where can I can go? Something they may not have known before or haven't had any idea at all [...]. Or if my neighbour tells me, you know, if you want to go out, then just walk into the Schleng-Park then the person also thinks, yes nice, but if I don't know where the Schleng-Park is and I'm new here then it can be very very helpful, if the route is drawn in correctly and the you have about an idea where to go.

The director of the community centre also saw a value for (older) people with mobility issues. On the one hand because the service provides routes with "various difficulty levels":

And they [the walks] are all regarding the length I find them wonderful to walk, that's also my opinion, even with people with walkers you can walk 2.4 kilometers or 1.8 or what ever $[\ldots]$ and I find that quite good that you simply have different possibilities.

On the other hand, she also considered the service relevant for people who cannot move outside and with the help of the service can "follow the route virtually". Furthermore, she saw a value for older people with dementia: 
Our dementia patients, for whom this is also is a great event, even if they may not be able to cope with it in the same way, but perhaps to evoke memories, right, of the past.

The director of the community centre further considered the service particularly relevant for older people with little money, who cannot afford to spend a lot of money for travelling:

And especially in Hemelingen and especially with not only the age structure, but also with the financial structure in this neighbourhood and in this district [...] Mahndorf is bourgeois, but in particular here in Hemelingen or also in Sebaldsbrïck we have of course also many fellow citizens who simply have no money at all or little and certainly not at all to arrange leisure time.

In addition, to not having the chance to travel abroad, she saw a general value in „creating experiences that lay right on the door step" also in order to create a better image of the district. This is supported by the statement of a participant that also affirms the increasing relevance of the local environment in older age:

Why wander far away, good things are so close.

The social activities manager mentioned the issue of loneliness and fear that in her opinion is addressed by the service. Because as she says for older people "walking alone is associated with fears". And one of the participants added the social dimension and said

The tendency is always 'I don't have anyone to go with me' or so, [...] then you can make an appointment if you want to do this or if you want to do that. And then it always goes 'If the others would, then I could' or so. This inertia [...] it's basically like this that many people say 'I shall go to the park alone?!' or something. I mean, the best example is Mr G, an Arbergen resident who says 'I've never been to this park', that fascinates me.

\section{Value for Intermediaries and Service Providers}

While all stakeholders see a substantial value in the service for older adults, the service providers are not all convinced of the relevance it will have for their work. When asked if they could imagine if and how the walking guide could support them in their work, some are less enthusiastic than others. However, two service providers announced to conduct further walks, using our digital district guide. The neighbourhood manager sees a supporting function in the service for her work, since she often acts as a contact person for all kinds of questions of especially older adults:

So perhaps it is another support, if you have eight walks or ten walks on such a page or in such a brochure and if somehow one is attacked with such questions like 'where can I go for a walk here at all? There is nothing here' [...] and then one can say, 'yes you can go to the Schlengpark or where else can you go' and then you are considering and then you would have the guide and can open it and say, 'look, there you can, there you can, there'. So you would have something compiled on which you can fall back, which did not yet exist. [...] or 'just have a look at the website, there are ten, twelve suggestions, where you can walk nice routes and, uh, get to know other things without using the car or just by train and bus or maybe actually by bike'. 
This relative lack of seeing an immediate benefit for the own work may be due to the fact that the intermediaries have been involved-foremostly-as supporters of the process. If we had considered the user role more strongly, we would have set-up a second small co-creation group that looks at the ways they organise and announce walks, the problems they encounter and how a digital service might be helpful. In a final discussion, there was the idea that a separate editing function might support designing and printing the announcement of walks which are pinned on news boards. Another option might be a calendar function with the walks that are offered by different service providers with an online registration, so everybody can see how many people are expected to participate. In a kind of community building even volunteers might suggest or announce walks by themselves on such a platform.

A separate subject is the value with regard to e-inclusion. The director of the association for social work, who was planning to organise ICT courses for older adults, wants to use the walking guide:

Then we will also open a group here for people who have never been engaged with these media before. [...] and then we want to show them that it's not that bad, that you can really do something [...] And then I wanted to take your page just as an example, right? So one shows them 'look' so they can see, that the Internet can also be used very quickly for one's own gain, right?

Further ICT courses are planned by two service providers.

\section{Value for Government}

The following table shows how the service relates to the objectives of the recent political priorities and central issues with regard to seniors defined by the State Ministry of Social Affairs, Women and Seniors (Table 13).

The service supports all four policy objectives and thereby the ministry can support similar processes in other districts of Bremen.

Table 13 Evaluating the value for government

\begin{tabular}{l|l}
\hline Political objectives & Corresponding part of the guide \\
\hline $\begin{array}{l}\text { The district as home } \\
\begin{array}{l}\text { Districts are central for integration and social } \\
\text { participation and politics should support people to stay } \\
\text { in the district as long as possible (ageing in place) }\end{array}\end{array}$ & $\begin{array}{l}\text { The guide informs older adults of nice } \\
\text { places and walks and thereby helps } \\
\text { creating an image of the district as } \\
\text { worth living }\end{array}$ \\
\hline $\begin{array}{l}\text { "Stadt in Bewegung" [City/Citizens in motion] } \\
\text { Physical exercises (indoor and outdoor, e.g. in sporting } \\
\text { clubs) shall be supported }\end{array}$ & $\begin{array}{l}\text { The guide informs about walking } \\
\text { routes and shall motivate older people } \\
\text { to exercise outside }\end{array}$ \\
\hline $\begin{array}{l}\text { Living together in a growing city } \\
\text { Opportunities for social participation will be improved } \\
\text { in order to develop the city and improve tolerance for } \\
\text { differences }\end{array}$ & $\begin{array}{l}\text { The guide offers the possibility to } \\
\text { organize joint walks and thereby } \\
\text { supports the social participation of } \\
\text { older adults }\end{array}$ \\
\hline Good services for the city and its people & $\begin{array}{l}\text { The guide itself is a good service for } \\
\text { the district and its image as well as for } \\
\text { the people }\end{array}$ \\
\hline
\end{tabular}




\section{Outcome and Impact}

In order to evaluate the outcome of our co-creation projects in Bremen Osterholz and Bremen Hemelingen, we conducted a survey amongst intermediaries and service providers working in these districts from December 2018 to January 2019.

\section{Sustainability: Commitment for the Maintenance of the Service}

The commitment of the intermediaries to the project and the outcome was in general quite high. The majority felt responsible for the content, even if only for parts of it (those parts where they have expertise mostly). Only 3 out of 10 did not feel responsible at all (Fig. 18).

Most of the service providers reviewed the content in order to detect errors or missing information. Of those who did, most reported those errors (Fig. 19).

Fig. 18 Perceived responsibility for maintenance of information

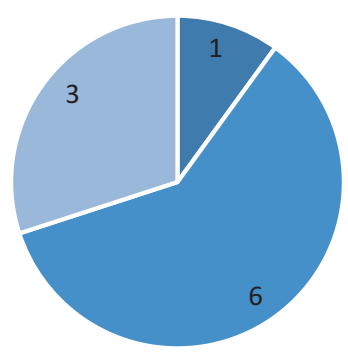

- Yes, for all information $\quad$ Yes, for parts of the content $\quad$ Not at all

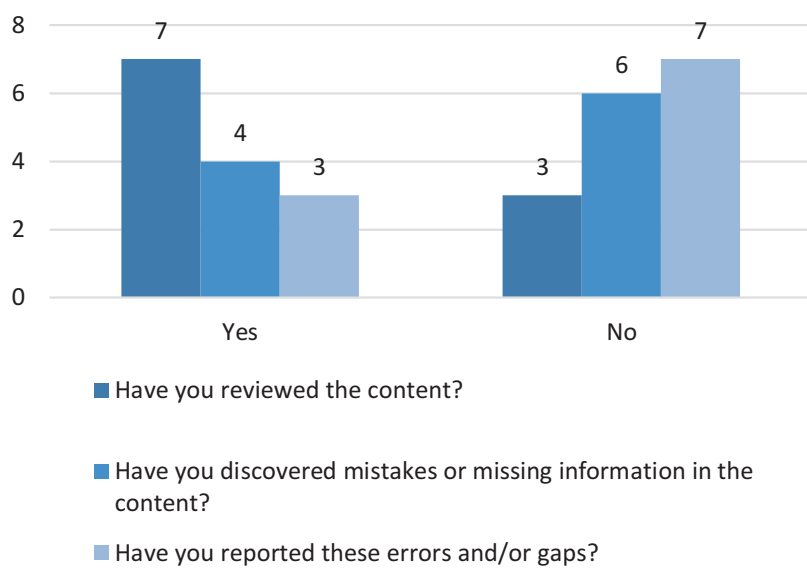

Fig. 19 Maintenance 


\section{Relevance}

The printed versions of the guidebook are used by most of the intermediaries in their work with older adults. The two heads of the district councils use the brochures in their contact to older citizens, e.g. at neighbourhood meetings. They are also available at the city office in the district and are given to people e.g. at change of registration and passport extensions. The social service providers and social workers distribute the brochures in their own offices and are well received. The digital services are used by intermediaries in their regular tablet/ICT courses. Furthermore, they are used by the social service providers and social workers when their older customers ask about offers for seniors in the district (Fig. 20).

The intermediaries mainly estimate the service (web pages and printed) as being relevant for the support of older adults social connectedness, with $80 \%$ stating that the digital service is very relevant or relevant.

\section{Dissemination}

Half of the interviewed intermediaries have referred the service to colleagues, in particular the web pages. The members of the district administration state to have pointed out the service in meetings to colleagues from other districts of the city. One of the local district council heads was so enthusiastic, he set-up a number of meetings between the researchers from ifib and other district councils. This led to another co-creation project in one of Bremen's districts which was financed by the district itself. Others disseminated the services by linking to the web pages on their own website. The social service providers and social workers that were interviewed recommended it to their employees or to colleagues in senior citizens centres.

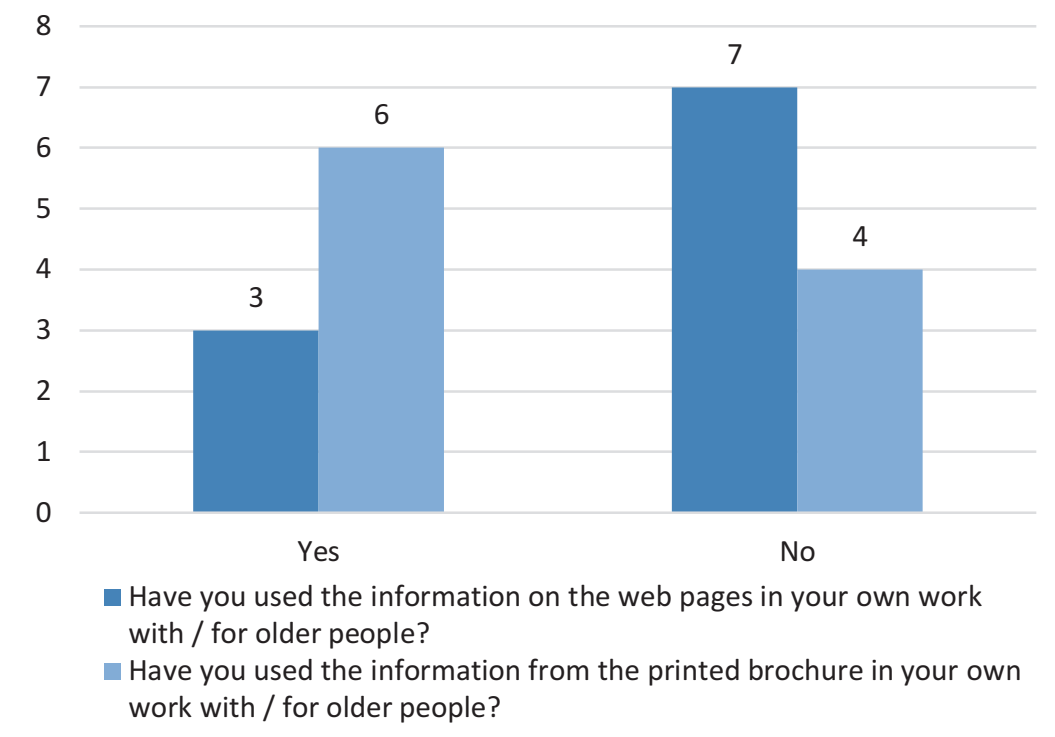

Fig. 20 Relevance of the service for the work with older adults 


\section{Impact of the Co-creation Projects}

Finally, we asked the intermediaries in an open question for their assessment of the outcome and impact of the project as a whole for older adults in the district. Five main aspects were mentioned:

- The projects have contributed to more comprehensive information for older adults about the district.

- They have stimulated older residents to engage with digital media.

- They have facilitated the emergence of new services and courses such as tablet, PC and internet groups for older adults.

- They have facilitated social encounters amongst older inhabitants and thereby supported their social connectedness.

- They have given older residents the feeling of being valued and heard, and have encouraged them to play an active role and help shape the future of their neighbourhoods and districts.

Asked for the impact of the project on their work interviewees mentioned the following:

- Getting to know the district better;

- Extending their own service portfolio (pc/internet/tablet group);

- Being supported in the advocacy for older people's interests and rights;

- Expanding contacts to senior networks \& to the older residents themselves;

- Being supported in advisory activities for older adults by the information/materials created in the project.

\section{Lessons Learned}

In the first co-creation project in Bremen Osterholz, we learned a lot with regard to all streams of our co-creation model and developed a set of lessons learnd for the second co-creation project in Bremen Hemelingen. In the following, I recall these lessons learned, show what actions had been taken and what lessons learned can be drawn.

\section{Governing and Managing Co-creation}

\begin{tabular}{l|l|l}
\hline $\begin{array}{l}\text { Lessons learned } \\
\text { derived from } \\
\text { Osterholz }\end{array}$ & $\begin{array}{l}\text { Actions to be implemented in } \\
\text { second co-creation process }\end{array}$ & Actions taken in Hemelingen \\
\hline $\begin{array}{l}\text { O-1.1: Start with } \\
\text { an existing group } \\
\begin{array}{l}\text { of relevant data } \\
\text { providers }\end{array}\end{array}$ & $\begin{array}{l}\text { Identify a district in which a } \\
\text { printed neighbourhood guide } \\
\text { already exists as a basis for data } \\
\text { and identify the group of people } \\
\text { that produced it }\end{array}$ & $\begin{array}{l}\text { The media agency from the first } \\
\text { co-creation process had edited a printed } \\
\text { district guide for Hemelingen in 2016 in } \\
\text { collaboration with the network "Alte } \\
\text { Vielfalt". They provided these data for } \\
\text { our intended digital guide }\end{array}$ \\
\hline
\end{tabular}


In the early phase of idea formation, the focus shifted from a comprehensive guide on services to more in depth information of nice places and walks. Therefore, the relevance of available open data decreased. However, the existence of printed guides was still a good starting point as they provide the benchmark for an improved digital multimedia service.

Lesson H-1.1: Get an overview on existing printed information in the domain of your problem focus and take them as a starting point and benchmark for an improved service that exploits the full potential of digital multimedia technologies. One of the main assumptions of Mobile Age was that co-created services for older adults would run on open government data. This has not been the case for Bremen. Governmental institutions did not provide the most relevant data. Rather, local service providers have proven to be the most important data sources relevant to older adults.

\begin{tabular}{l|l|l}
\hline $\begin{array}{l}\text { Lessons learned } \\
\text { derived from } \\
\text { Osterholz }\end{array}$ & $\begin{array}{l}\text { Actions to be implemented in second } \\
\text { co-creation process }\end{array}$ & $\begin{array}{l}\text { Actions taken in } \\
\text { Hemelingen }\end{array}$ \\
\hline $\begin{array}{l}\text { O-1.2: Establish } \\
\text { project group of local } \\
\text { stakeholders }\end{array}$ & $\begin{array}{l}\text { Identify a district in which a network of service } \\
\text { providers already collaborates and which may } \\
\text { be interested in extending their collaboration to } \\
\text { the development of a digital district guide }\end{array}$ & $\begin{array}{l}\text { Members of "Alte } \\
\text { Vielfalt" became part } \\
\text { of project board }\end{array}$ \\
\hline
\end{tabular}

The printed district guide had been developed with several intermediaries that cooperated in the network "Alte Vielfalt". They were editing a second edition of a district reader. They agreed to engage in a project board in order to support a complementary service to these printed guides. The collaboration with the Network "Alte Vielfalt" was helpful and beneficial to the process in several respects:

- It served as a means to legitimise the project in front of the local district council as something regarded beneficial by local stakeholders.

- It enabled us to have a positive press-coverage featuring relevant local stakeholders.

- It supported the recruitment of older adults.

- It ensured that we would develop a service relevant to local services providers.

- It ensured the sustainability of the service, because local stakeholders volunteered to maintain it.

We realised that only those members of the network participated who benefited most directly from the new service.

Lesson H-1.2: Start a co-creation process in collaboration with an existing network of intermediaries and service providers, who ideally have experience in collecting, editing and providing information for older adults and an interest in improving their role as information brokers. 


\begin{tabular}{l|l|l}
\hline $\begin{array}{l}\text { Lessons learned } \\
\text { derived from } \\
\text { Osterholz }\end{array}$ & $\begin{array}{l}\text { Actions to be implemented in } \\
\text { second co-creation process }\end{array}$ & Actions taken in Hemelingen \\
\hline $\begin{array}{l}\text { O-1.3.: Consider } \\
\text { activities that } \\
\text { are feasible }\end{array}$ & $\begin{array}{l}\text { Cut down on the cultural } \\
\text { probes pack, to make it less } \\
\text { time consuming for } \\
\text { participants and facilitators }\end{array}$ & $\begin{array}{l}\text { The cultural probes were reduced to a } \\
\text { questionnaire booklet, that allowed us to gain } \\
\text { an overview about our participants } \\
\text { technology use practices and relationship } \\
\text { with the district }\end{array}$ \\
\hline
\end{tabular}

In the second process, the probes pack had been reduced to a questionnaire instead of several tools for self-documentation. This was not welcomed by all participants. We had to realise that there is no "one-size-fits-many" option for probes. We found that amongst our target audience, a particular mistrust is prevalent when it comes to the disclosure of any kind of personal information. There needs to be an established and trusted relationship between facilitators and participants before introducing probes (or similar methods).

Lesson H-1.3: Written personal information of participants may only be collected during the co-creation process if necessary (e.g. for idea formation), and must be discussed and explained to participants in advance. The material needs to be tailored to the capabilities and realities of the persons involved.

\begin{tabular}{l|l|l}
\hline $\begin{array}{l}\text { Lessons learned derived } \\
\text { from Osterholz }\end{array}$ & $\begin{array}{l}\text { Actions to be implemented in second } \\
\text { co-creation process }\end{array}$ & Actions taken in Hemelingen \\
\hline $\begin{array}{l}\text { O-1.4.: Consider } \\
\text { activities that support use } \\
\text { of technology }\end{array}$ & $\begin{array}{l}\text { Allow more time in the co-creation } \\
\text { process for participants to get } \\
\text { acquainted with technology. } \\
\text { Offer support clinics outside of the } \\
\text { core co-creation activities }\end{array}$ & $\begin{array}{l}\text { We introduced the tablets } \\
\text { earlier on in the process. } \\
\text { We offered some additional } \\
\text { training to non-tech savvy } \\
\text { participants }\end{array}$ \\
\hline
\end{tabular}

We addressed this recommendation through a number of action points. Learning from Osterholz, we introduced the tablets earlier on in the process and offered some additional training to non-tech savvy participants. The training sessions were welcomed by our collaborating service providers as well as participants. For the cocreation process itself however, we had to realise that our training sessions were not sufficient to enable digitally illiterate participants to fully engage in technologyrelated activities and overcome, the imbalance in technological know-how amongst our core group of older adults.

H-1.4: Offer additional training to non-tech savvy participants, should they be interested in learning more about technology. 


\begin{tabular}{l|l|l}
\hline $\begin{array}{l}\text { Lessons learned derived } \\
\text { from Osterholz }\end{array}$ & $\begin{array}{l}\text { Actions to be implemented in second } \\
\text { co-creation process }\end{array}$ & Actions taken in Hemelingen \\
\hline $\begin{array}{l}\text { O-1.5: Establish } \\
\text { transparent decision- } \\
\text { making procedures }\end{array}$ & $\begin{array}{l}\text { Establish a procedure to document } \\
\text { the process and decision-making to } \\
\text { all participating stakeholders }\end{array}$ & $\begin{array}{l}\text { We documented all our } \\
\text { activities in a blog and } \\
\text { circulated meeting minutes }\end{array}$ \\
\hline
\end{tabular}

As pointed out above, the decision making process was meant to be more transparent (e.g. through our activity blog). However, only few participating older adults consulted the blog, partly because they did not look for information in the internet; partly because they felt no need to follow the decision making process. In contrast, the blog was used and found useful by our project board of service providers and intermediaries.

H-1.5: Making the documentation and communication of activities and its results available to all involved stakeholders via suitable channels is indispensable for co-creation processes in order to ensure equal opportunities to exert influence among all involved stakeholders.

\section{Engaging Stakeholders}

\begin{tabular}{l|l|l}
\hline $\begin{array}{l}\text { Recommendations derived } \\
\text { from Osterholz }\end{array}$ & $\begin{array}{l}\text { Actions to be implemented in second } \\
\text { co-creation process }\end{array}$ & $\begin{array}{l}\text { Actions taken in } \\
\text { Hemelingen }\end{array}$ \\
\hline $\begin{array}{l}\text { O-2.1: Identify the role of } \\
\text { intermediaries in } \\
\text { co-creation process }\end{array}$ & $\begin{array}{l}\text { Consider the different roles of } \\
\text { intermediaries and explain } \\
\text { expectations well in advance (e.g. } \\
\text { role of local government, role of } \\
\text { service providers in process) }\end{array}$ & $\begin{array}{l}\text { Network "Alte Vielfalt" } \\
\text { became our gate-keeper; } \\
\text { local government } \\
\text { endorsed the process }\end{array}$ \\
\hline
\end{tabular}

The close collaboration with intermediaries was beneficial to the co-creation process in several ways:

- They acted as gate-keeper to local government and supported the recruitment of older adults (see also O-2.3)

- They acted as champions of our project and endorsed the process during council meetings.

- They acted as communicators by promoting the project in the local newspapers, their own publications and the district fair.

- They served as data providers with data about their own services and resources.

- They will ensure the sustainability of the service.

Lesson H-1.2: Intermediaries can take different supporting roles in co-creation processes. However, the prerequisite for their commitment is that the outcome will benefit their work. 


\begin{tabular}{l|l|l}
\hline $\begin{array}{l}\text { Lessons learned } \\
\text { derived from } \\
\text { Osterholz }\end{array}$ & $\begin{array}{l}\text { Actions to be implemented in } \\
\text { second co-creation process }\end{array}$ & Actions taken in Hemelingen \\
\hline $\begin{array}{l}\text { O-2.2: Consider } \\
\text { context in which } \\
\text { older adults are } \\
\text { invited to participate }\end{array}$ & $\begin{array}{l}\text { Identify a network/group of service } \\
\text { and care providers which can host } \\
\text { the co-creation process within the } \\
\text { context of their work }\end{array}$ & $\begin{array}{l}\text { We conducted the neighbourhood } \\
\text { walks in cooperation with a senior } \\
\text { citizen meeting centre as part of } \\
\text { their service offers }\end{array}$ \\
\hline
\end{tabular}

In Hemelingen, we aligned our co-creation process closer to the services and resources of local social care service providers and intermediaries. Older adults were invited to participate as part of the service offerings of these service providers. We hence, circumvented "cold recruiting" as in Osterholz but embedded our project as part of the existing service infrastructures. For example, the meeting places offer a variety of courses and meetings. They were ideally positioned to adopt our tablet courses as part of their offers. Likewise did the neighbourhood walks fit well to the services provided by some of our collaborating service providers. Recruitment is hence more effective, as these service providers are already actively involving a broad range of older adults from the district. The drawback might be that some people might not feel addressed by certain places/organisers (e.g. the church, a certain neighbourhood).

Lesson H-2.2: When embedding the process in existing services and activities be aware that only a certain part of the target group might be addressed (e.g through the church or in particular neighbourhoods). Consider to organise activities at different hosts and places.

\begin{tabular}{l|l|l}
\hline $\begin{array}{l}\text { Lessons learned } \\
\text { derived from Osterholz }\end{array}$ & $\begin{array}{l}\text { Actions to be implemented in } \\
\text { second co-creation process }\end{array}$ & Actions taken in Hemelingen \\
\hline $\begin{array}{l}\text { O-2.3: Engage } \\
\text { intermediaries to } \\
\text { support recruitment }\end{array}$ & $\begin{array}{l}\text { Identify a network/group of service } \\
\text { and care providers, which facilitate } \\
\text { recruitment within the context of } \\
\text { their work }\end{array}$ & $\begin{array}{l}\text { For our first round of focus } \\
\text { groups, network members (“Alte } \\
\text { Vielfalt") recruited some of } \\
\text { their customers }\end{array}$ \\
\hline
\end{tabular}

Intermediaries facilitated the recruitment of older adults mainly in two ways:

- Explorative focus groups with groups of older adults with very different skills and needs. These included:

- A group of older adults with mental health issues

- A group of older adults who regularly participate in activities from the protestant church congregation in the neighbourhood of Hemelingen

- A group of older adults from a seniors residence home 
- Recruitment of older adults for walks and walking workshops through the intermediaries' communication channels.

As we were aiming to collaborate with service providers whose service portfolio could potentially be complemented with the digital district guide, we expected that they would also provide the most effective access to older adults interested in and in need of such a service. This was only partially true. In particular, the group of older adults with mental health issues and the group of older adults from the senior residence home did not participate in the co-creation activities beyond the two scheduled focus groups. This way of recruitment however, allows validating the service idea with groups of older adults that cannot participate throughout the whole life cycle of such as project.

Lesson H-2.3: Engaging intermediaries for the recruitment requires a deep understanding and commitment of these intermediaries to the co-creation process.

\begin{tabular}{l|l|l}
\hline $\begin{array}{l}\text { Lessons } \\
\text { learned } \\
\text { derived from } \\
\text { Osterholz }\end{array}$ & $\begin{array}{l}\text { Actions to be implemented in second } \\
\text { co-creation process }\end{array}$ & Actions taken in Hemelingen \\
\hline $\begin{array}{l}\text { O-2.4: } \\
\text { Establish } \\
\text { older adults as } \\
\text { experts }\end{array}$ & $\begin{array}{l}\text { If activities such as cultural probes are } \\
\text { reduced }(\mathrm{O}-1.1), \text { find new ways of } \\
\text { establishing older adults' expertise } \\
\text { early on in the process and allow them } \\
\text { to reflect on their practices for } \\
\text { identifying needs and resources }\end{array}$ & $\begin{array}{l}\text { While conducting the walks, many of } \\
\text { the participants had a lot of knowledge } \\
\text { to share about the district. The walks } \\
\text { became a lived experience of } \\
\text { demonstrating expertise (e.g. about the } \\
\text { district) }\end{array}$ \\
\hline
\end{tabular}

As argued earlier, it is important to establish older adults as experts in a cocreation process in order to level out some of the power imbalances that are present in any collaboration project. The walks and walking workshops were an ideal format in which participants could demonstrate their local knowledge and expertise. They were particularly helpful for prompting participants to speak about certain places, streets, etc; something that was at times more difficult for our participants in Osterholz, when they had to report on nice places in a closed workshop environment. In addition, some participants had above average technical expertise, e.g. on Open Street Map or video editing.

Lesson H-2.4: In order to establish older adults as experts, the different kinds of experience and expertise that people have, need to be articulated and appreciated equally. 


\begin{tabular}{l|l|l}
\hline $\begin{array}{l}\text { Lessons } \\
\text { learned } \\
\text { derived from } \\
\text { Osterholz }\end{array}$ & $\begin{array}{l}\text { Actions to be implemented in } \\
\text { second co-creation process }\end{array}$ & Actions taken in Hemelingen \\
\hline $\begin{array}{l}\text { O-2.5: } \\
\begin{array}{l}\text { Facilitate role } \\
\text { shift of older } \\
\text { adults }\end{array}\end{array}$ & $\begin{array}{l}\text { Define the co-creation process } \\
\text { in a transparent and clear way. } \\
\text { Communicate tasks early on. } \\
\text { Identify interests and abilities of } \\
\text { participating older adults }\end{array}$ & $\begin{array}{l}\text { We recruited the older adults first for the } \\
\text { walks and later on for the design and data } \\
\text { collection of the digital neighbourhood guide. } \\
\text { This was communicated early on and a good } \\
\text { mix of local knowledge and technical } \\
\text { expertise was assembled }\end{array}$ \\
\hline
\end{tabular}

In Osterholz, we experienced that participants found it difficult to shift between different roles and tasks throughout the co-creation process. For Hemelingen, we proposed to identify interests and abilities of the participating older adults, and include them accordingly. For example, we included some older adults only in a few focus groups because they would not commit to a long process. However, some participants experienced this fragmentary user participation as dissatisfactory as the vision and idea for the service had to be continuously negotiated throughout the process while new participants joined and left the process. A core group of older adults as co-creators seems the most suitable form.

Lesson H-2.5. Consider a core group of older adults as co-creators that engage over the entire process and where each participant contributes to different tasks that fit her/his interests and abilities and are defined jointly in the beginning. From the start, facilitators should announce that they will engage additional co-creators when there is consent that certain additional input or expertise are required.

\section{Co-creating a Service Concept}

\begin{tabular}{l|l|l}
\hline $\begin{array}{l}\text { Recommendations derived from } \\
\text { Osterholz }\end{array}$ & $\begin{array}{l}\text { Actions to be implemented } \\
\text { in second co-creation } \\
\text { process }\end{array}$ & Actions taken in Hemelingen \\
\hline $\begin{array}{l}\text { O-3.1: Consider methods that } \\
\text { connect different activities and } \\
\text { relate to defining characteristics of } \\
\text { the target group }\end{array}$ & $\begin{array}{l}\text { Use methods that connect } \\
\text { different activities and } \\
\text { allow for the refinement of } \\
\text { the target user groups }\end{array}$ & $\begin{array}{l}\text { The walks served as a thread, } \\
\text { that served for the definition of } \\
\text { attributes, the collection of } \\
\text { data and also the design of the } \\
\text { front-end }\end{array}$ \\
\hline
\end{tabular}

Personas and scenarios were helpful methods for providing a thread through our co-creation process in Osterholz. This works however only with a somewhat stable group of participants. As we planned to conduct a more open process in Hemelingen, 
we needed to design the process in a way that we could use other methods to connect different activities and keep the project somewhat framed. In Hemelingen, the walks served as a thread through which we defined attributes, collected data and also design the front-end. The walks themselves hence became a reference point. And even though not all participants participated in all walks, they were similar enough to serve as a joint reference. This was for example also facilitated through the template questionnaire that we had developed for the walks and which participants completed while walking.

Lesson H-3.1: Depending on the problem focus and the service to be developed, personas \& scenarios or walks may be suitable methods to define a thread throughout the co-creation process and connect different activities.

\begin{tabular}{l|l|l}
\hline $\begin{array}{l}\text { Lessons learned } \\
\text { derived from } \\
\text { Osterholz }\end{array}$ & $\begin{array}{l}\text { Actions to be } \\
\text { implemented in second } \\
\text { co-creation process }\end{array}$ & Actions taken in Hemelingen \\
\hline $\begin{array}{l}\text { O-3.2: Consider } \\
\text { intermediaries as } \\
\text { main users of a } \\
\text { service }\end{array}$ & $\begin{array}{l}\text { Identify intermediaries, } \\
\text { such as service and care } \\
\text { providers and investigate } \\
\text { how a digital service } \\
\text { could support their work. }\end{array}$ & $\begin{array}{l}\text { We considered the intermediaries and services } \\
\text { providers as organisers of joint walks for older } \\
\text { adults in a disseminating role. Since some of } \\
\text { the members of the project board, provide } \\
\text { activities, such as walks for older adults, the } \\
\text { service is meant to support their work by } \\
\text { facilitating the planning and organisation of } \\
\text { joint activities for older adults }\end{array}$ \\
\hline
\end{tabular}

In Hemelingen, we collaborated closely with intermediaries by involving them substantially throughout the whole process. They contributed in many respects (see O-2.1 above). Besides their support of our work a main reason was that we considered them as target group of the service and thus considered them as future users. The guide is valuable since it serves as source of information to which they can refer when asked by their customers. In addition, we worked out a supporting functionality for those service providers offering walks to senior citizens.

Lesson H-3.2: Intermediaries need to be substantially involved in the cocreation of services for older adults from the beginning. Ideally, the service concept is developed in close cooperation with intermediaries in order to ensure its relevance. 


\begin{tabular}{l|l|l}
\hline $\begin{array}{l}\text { Lessons learned derived } \\
\text { from Osterholz }\end{array}$ & $\begin{array}{l}\text { Actions to be } \\
\text { implemented in second } \\
\text { co-creation process }\end{array}$ & Actions taken in Hemelingen \\
\hline $\begin{array}{l}\text { O-3.3: Consider a service } \\
\text { that is more activating/ } \\
\text { beyond information } \\
\text { provision }\end{array}$ & $\begin{array}{l}\text { Identify and implement } \\
\text { potential services that } \\
\text { could complement the } \\
\text { information provided in a } \\
\text { digital district guide }\end{array}$ & $\begin{array}{l}\text { Beyond the mere provision of } \\
\text { information about nice places, the } \\
\text { digital district guide now provides } \\
\text { information about walks. In addition, } \\
\text { local service providers offer walks to } \\
\text { older residents as part of the digital } \\
\text { district guide service }\end{array}$ \\
\hline
\end{tabular}

As outlined in the introduction to this book, there is a difference between providing information about services and providing services as such. We have moved beyond mere information provision with the Hemelingen demonstrator and potentially a step further towards (online) interaction and activation.

Lesson H-3.3: With regard to social inclusion, a service should focus more on specific forms of participation in the neighbourhood and provide information that is activating, and hence actively supporting social inclusion.

\section{Working with (Open) Data}

\begin{tabular}{l|l|l}
\hline $\begin{array}{l}\text { Lesson learned derived from } \\
\text { Osterholz }\end{array}$ & $\begin{array}{l}\text { Actions to be implemented in second } \\
\text { co-creation process }\end{array}$ & $\begin{array}{l}\text { Actions taken in } \\
\text { Hemelingen }\end{array}$ \\
\hline $\begin{array}{l}\text { O-4.1: Take into account that } \\
\text { information identified as } \\
\text { relevant may not be available } \\
\text { as open data }\end{array}$ & $\begin{array}{l}\text { Plan ahead to collaborate with various } \\
\text { data owners (e.g. service providers) and } \\
\text { allow sufficient time for data creation } \\
\text { during the co-creation process. } \\
\text { Offer a user-friendly backend for } \\
\text { inputting data to participants }\end{array}$ & $\begin{array}{l}\text { We obtained the data } \\
\text { from the printed } \\
\text { district map. } \\
\text { We offered a user- } \\
\text { friendly back-end } \\
\text { solution for data input }\end{array}$ \\
\hline
\end{tabular}

We initiated early on in the field work in Hemelingen a survey on existing data (also in printed versions) and collaborated with data providers. We also offered userfriendly back-end solutions for data input. This is the only viable way we saw for the use of data in co-creation processes.

Lesson H-4.1: There is a tension between data-driven app development and citizen-driven service co-creation as much of the information identified as relevant in co-creation processes is not available as open data. We are convinced that effective and relevant services for older adults should not be driven by what data is available, but rather have to be based on the needs and requirements of the target audience. 


\begin{tabular}{l|l}
\hline Lesson learned derived from Osterholz & $\begin{array}{l}\text { Actions to be implemented in second } \\
\text { co-creation process }\end{array}$ \\
\hline $\begin{array}{l}\text { O-4.2: Less is more. Concentrate on a few } \\
\text { categories of objects }\end{array}$ & $\begin{array}{l}\text { Agree on specific objects to be explored in } \\
\text { more detail }\end{array}$ \\
\hline
\end{tabular}

The work with data on so many different kinds of services in Osterholz was highly time consuming. Many of the participants engaged in the validation of information about meeting places, service providers etc. Such tasks can also be performed by others. The resources and expertise of older adults seem to be better used for tasks relating to objects that are not dealt with in the available guides and directories, i.e. nice places and walks. In Hemelingen, we concentrated on walks only and had the advantage of exploring a service around walks, much further than the nice places in Osterholz. This focus also allowed to include different multi-media features in our service (e.g. spoken comments and video clips were produced by some of our participants.)

Lesson H-4.2: Many older adults are very busy. Hence, their resources and commitment should be used in the most effective way (e.g. concentrating on the in-depth development of service concepts or data co-creation) and potentially allow for richer descriptions (e.g. through video and audio clips).

\begin{tabular}{|c|c|c|}
\hline $\begin{array}{l}\text { Lessons learned } \\
\text { derived from } \\
\text { Osterholz }\end{array}$ & $\begin{array}{l}\text { Actions to be implemented in } \\
\text { second co-creation process }\end{array}$ & Actions taken in Hemelingen \\
\hline $\begin{array}{l}\text { O-4.3: Consider } \\
\text { methods for } \\
\text { "snowball" data } \\
\text { collection }\end{array}$ & $\begin{array}{l}\text { Use methods that allow a } \\
\text { variety of older adults to } \\
\text { contribute to the data } \\
\text { collection }\end{array}$ & $\begin{array}{l}\text { Neighbourhood walks included around } \\
46 \text { older adults from the district that } \\
\text { contributed comments on relevant } \\
\text { aspects }\end{array}$ \\
\hline
\end{tabular}

We had about 46 older adults participating in six neighbourhood walks. Such activities had a low-threshold. Participants contributed to the further refinement of attributes and data. Towards the end of the project, several teams of older adults worked on individual walks. It was hence useful that the data collection tasks could be easily separated.

Lesson H-4.3: "Snowball" data collection allows for the contribution of the collective knowledge of a large group of people. It thereby enables older adults to contribute their expertise. 


\section{Co-creating Software}

\begin{tabular}{l|l}
\hline $\begin{array}{l}\text { Lesson learned derived from } \\
\text { Osterholz }\end{array}$ & Actions to be implemented in second co-creation process \\
\hline $\begin{array}{l}\text { O-5.1: Consider the reduction of } \\
\text { prototyping tasks }\end{array}$ & $\begin{array}{l}\text { Devote specific sessions to prototyping and only involve } \\
\text { those older adults interested. } \\
\text { Establish procedures to feed the continuous development } \\
\text { back to participants }\end{array}$ \\
\hline
\end{tabular}

Early on in the process, we conducted a number of focus groups to evaluate the design and functionality of the Osterholz demonstrator. We then conducted one paper prototyping session that was announced in advanced as being more technical. We started with a comprehensive overview over the objectives and tasks of the design session. We then left the decision to participants if they preferred to do the paper works themselves or not. They decided to jointly discuss the design in the group and leave the paper work to the facilitators.

Subsequently, the technical team presented their progress on digital versions and received feedback. Overall participants found this reduced prototyping tasks adequate. In order to increase the use of technologies, we encouraged participants to use the back-end of data creation and a software for creating slide shows.

Lesson H-5.1: Prototyping tasks need to be announced and explained well in advance so participants are given the opportunity to decide if and in what form they want to contribute.

\begin{tabular}{l|l}
\hline Lesson learned derived from Osterholz & $\begin{array}{l}\text { Actions to be implemented in second co-creation } \\
\text { process }\end{array}$ \\
\hline $\begin{array}{l}\text { O-5.2: Consider design of application } \\
\text { beyond design of user interface }\end{array}$ & $\begin{array}{l}\text { Consider design of data structures and back-end } \\
\text { functionality for data maintenance }\end{array}$ \\
\hline
\end{tabular}

The first walks and workshops were used to defined the data structures and attributes of the walks and the stops. The content management systems had been adapted and the description of the walks got beyond a set of attributes with texts.

Lesson H-5.2: Full co-creation in software development should not only deal with the user interface of the app but also provide a back-end that is easy to use for co-creators in providing and maintaining the input. 


\section{Sustainability}

\begin{tabular}{l|l}
\hline $\begin{array}{l}\text { Lesson learned derived } \\
\text { from Osterholz }\end{array}$ & Actions to be implemented in second co-creation process \\
\hline $\begin{array}{l}\text { O-6.1: Sustainability } \\
\text { remains a big challenge }\end{array}$ & $\begin{array}{l}\text { Identify local stakeholders that can sustain the maintenance of the } \\
\text { service early in the process (e.g. identify ways in which the service } \\
\text { serves their interests/supports their work) }\end{array}$ \\
\hline
\end{tabular}

Members of "Alte Vielfalt" became part of a project board and subsequently took over responsibility for the service maintenance (tablet courses, walks).

Lesson H-6.1: The willingness to commit to the maintenance of the service increases with the degree of involvement in the process and the degree of benefitting from its outcomes. Responsibilities for the maintenance should therefore be defined early in the process together with local stakeholders.

Open Access This chapter is licensed under the terms of the Creative Commons Attribution 4.0 International License (http://creativecommons.org/licenses/by/4.0/), which permits use, sharing, adaptation, distribution and reproduction in any medium or format, as long as you give appropriate credit to the original author(s) and the source, provide a link to the Creative Commons license and indicate if changes were made.

The images or other third party material in this chapter are included in the chapter's Creative Commons license, unless indicated otherwise in a credit line to the material. If material is not included in the chapter's Creative Commons license and your intended use is not permitted by statutory regulation or exceeds the permitted use, you will need to obtain permission directly from the copyright holder.

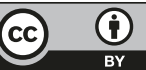

